\title{
الاثار الاتتصادية والاجتماعية للعقوبات الاقتصادية
}

\author{
shel \\ د./ مصطفى أحمد حامد رضوان \\ مدرس الاقتصاد والماليتّ العامه بمعهد \\ مصر العالى للتجارة والحاسبات بالمنصورة
}


تستهدف سياسة العقوبات الاقتصادية الدولية إحداث أثر سياسى كلى ينتج عنها خلال فترة منظورة ؛ وذلك من خلال تقليص قرات النظم الحاكمة المستهدفة بالعقوبـات على التحكم والسيطرة فى مقدراتها من خلال غلق كل او بعض المنافذ الاقتصادية التى

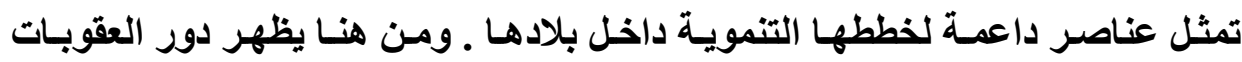

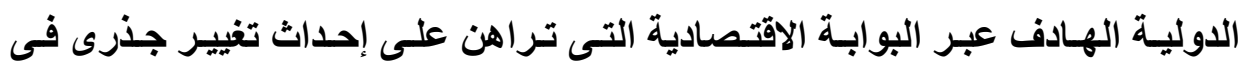

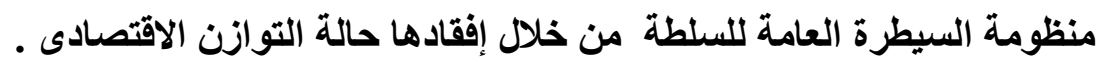
ومن ثم فإن العقوبات الاقتصادية الدولية ذات المنظور السياسى تتداخل مفصلياً

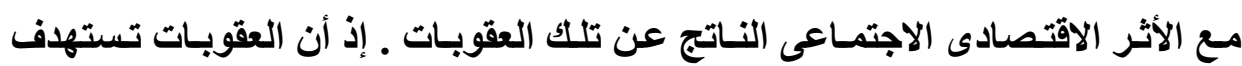
إلحاق خلل بنيوى بتوازن الاطار الكلى لاقتصاد الدولـة المستهدفة بالعقوبـات من خلادل

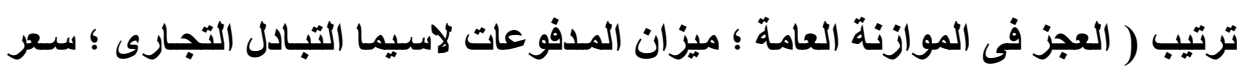

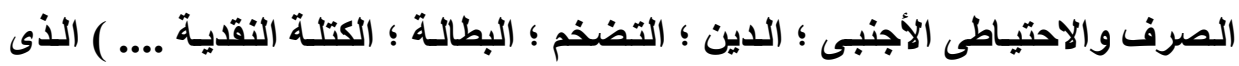

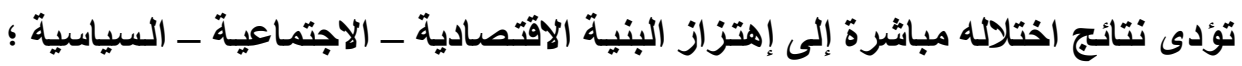

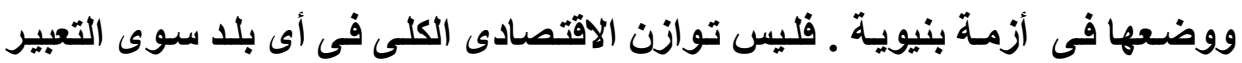
الاقتصادى عن الاستقرار الاجتماعى والسياسى . إشكالية الدراسة : تبـدو لنـا إثـكالية هـذه الدراسـة في محاولـة بحث وتحليـل الاثــار الاقتصادية والاجتماعية التى خلفتها وتخلفها العقوبات الاقتصادية الدولية على اقتصاديات الدول

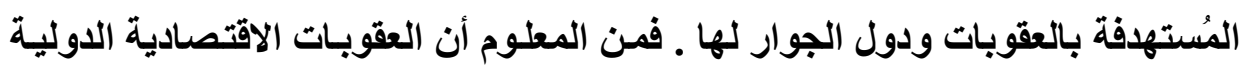

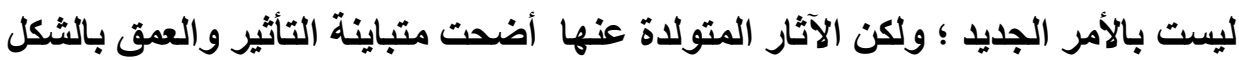

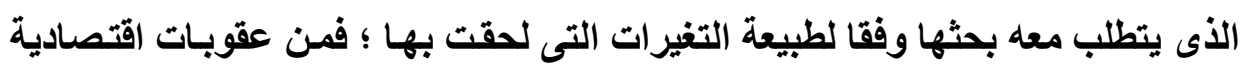

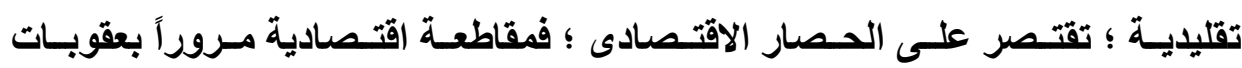

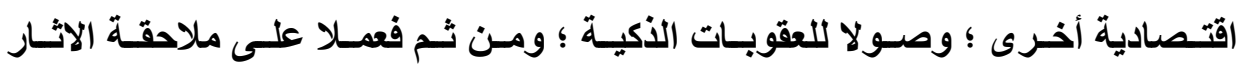


الاقتصادية المتطورة ؛ سنعمل جاهلين على إبراز ماهية تلك العقوبات ؛ وطبيعة الآثار

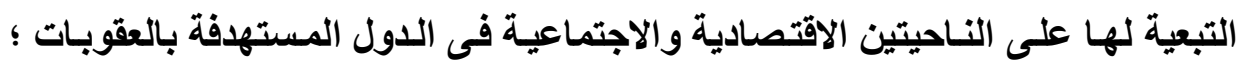

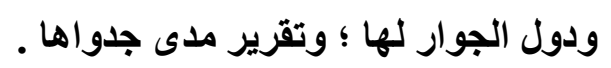

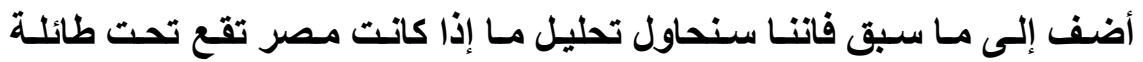

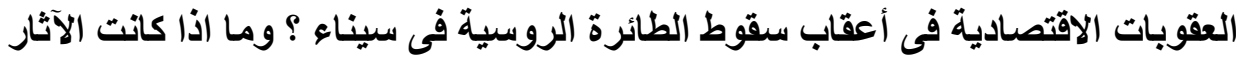

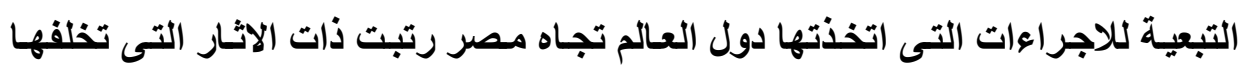
العقوبات الاقتصادية الدولية على الدول المستهدفة بالعقاب ؟

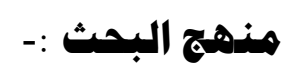

يرتكز المنهج المستخدم في هذا البحث علي الأسلوب الاستقرائى والتطبيقى ؛

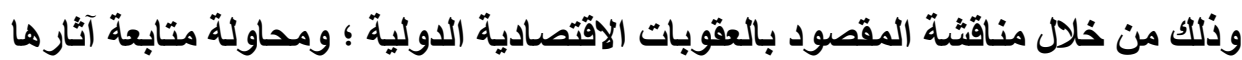

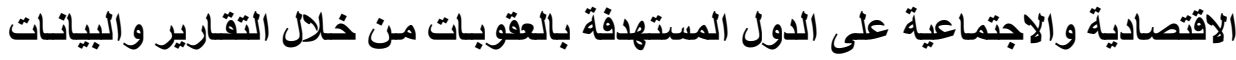

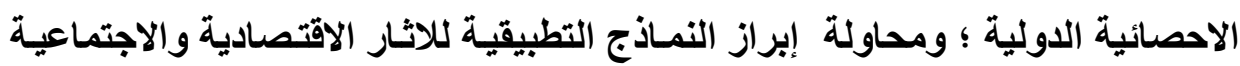

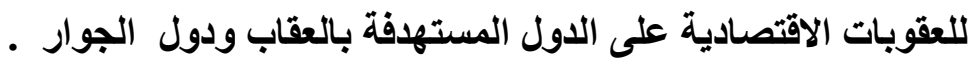

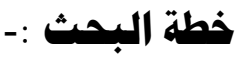

نصل تمهيدى : : تعريف العقوبات الاقتصادية الدولية_أهدافها - أنواعها -

$$
\text { صورها }
$$

الفـصل الأول :- الآثنار الاقتصادية للعقوبـات الاقتصادية الدوليـة على الدول

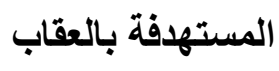

الفصل الثانى :- الآثار الاجتماعية للعقوبـات الاقتصادية الدولية على الدول

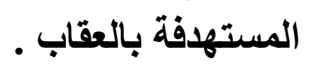

الفصل الثالث :- آثار العقوبات الاقتصادية على دول الجوار

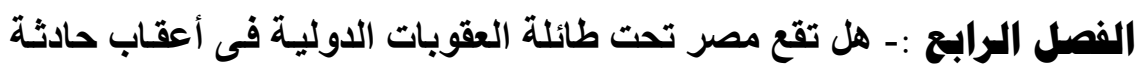

سقوط الطائرة الروسية فى سيناء ؟

$$
\text { الخاتمة والتوصيات }
$$




\section{فصل تمهيدى}

\section{تعريف العقوبات الاقتصادية الدولية-أهدافها - أنواءها - صورها}

$$
\text { أولا :- التعريف :- }
$$

لم تعط أياً من المواثيق الدولية(') تعريف محدد للعقوبـات الاقتصادية الدولية ؛ وإنما اقتصرت تلك المواثيق على تعداد بعض الوسـائل المستخدمة لتطبيق هذا النوع من العقوبات التى وردت على سبيل المثال لا الحصر(') .

أما فيما يتعلق بالتناول الفقهى لتحديد المقصود بالعقوبـات الاقتصادية الدولية

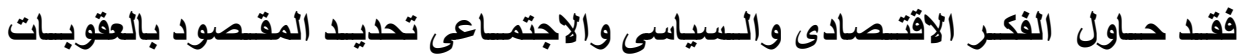
الاقتصادية الدولية وذلك على النحو التـالى :- يرى البعض أن العقوبـات الاقتصادية الاولية هى :- " آلية للقسر والإكراه فى السياسة الخارجية للاولة التى تنتهلك العلاقات الاقتصادية الطبيعية مع دولة أخرى ؛ وذلك من أجل حمل الدولة المستهدفة على تغيير سلوكها المسبب للعقاب الدولى " (")

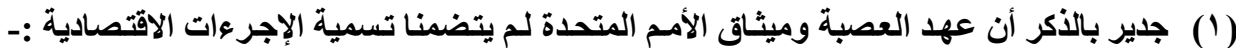

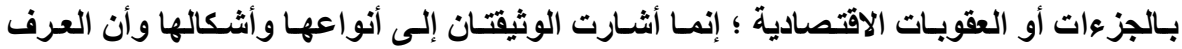

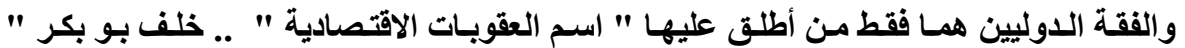

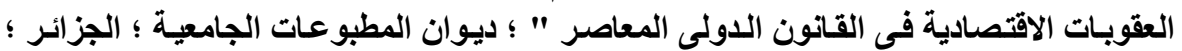

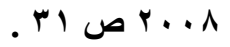

(ץ) و هو الأمر الذى يبدو أنه يرتد أساساً إلى تطور المجتمع الدولى وتطور الوسيائل التى يستخدمها

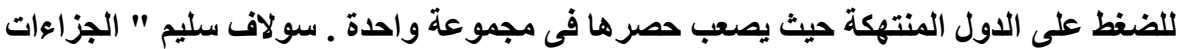

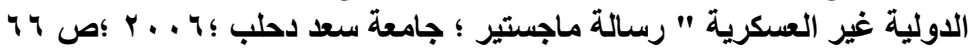

(3) Micah Kaplan, «North Korean Economic Sanctions», Journal of International Relations, Volume 9, Spring 2007, pp 68,69. 
فى حين ذهب البعض إلى أنها مرادفة للمقاطعة الاقتصادية و التى تغنى :- "

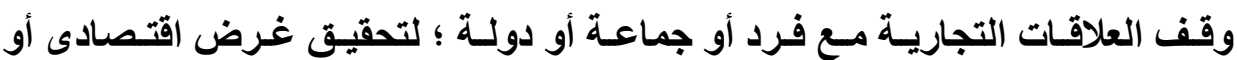

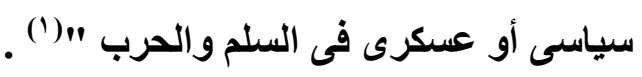

فى حين عرفها البعض على أنها :- " الحرمسان الفعلى أو التهديد باستعمال

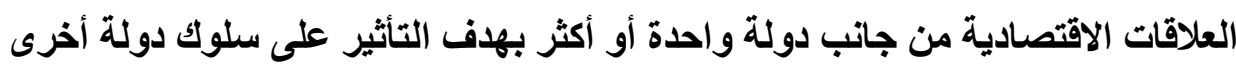
فى القضايا غير الاقتصادية أو الحد من قدراته العسكرية " (").

وفى تعريف أكثر دقة للعقوبـات الاقتصادية ذهب إلى أنها " إجراء اقتصادى

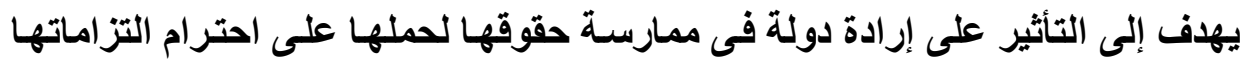

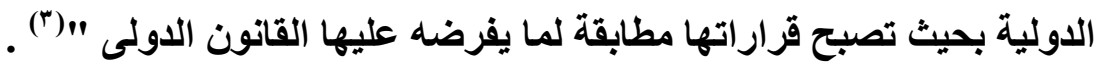
نخلص من كل ما سبق ؛ إلى أن العقوبات الاقتصادية الدولية تشتمل على عدد

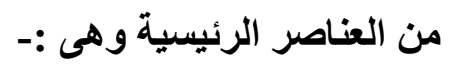

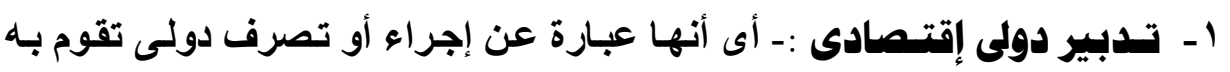

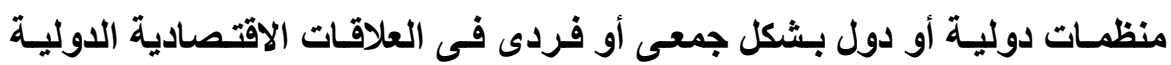

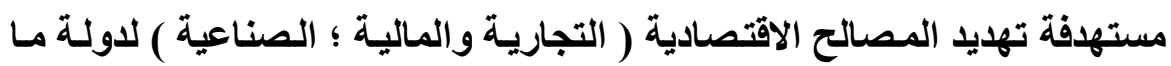

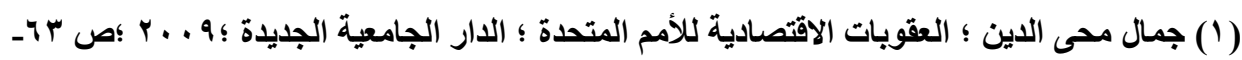
. 1 纟

(2) Ali Mostashari, " The Impacts of U.S. Sanctions on the Iranian Civil Society: Consequences for Democratization», p.1, Disponible sur le site internet

: www.news4iran.info/The\%20Impacts\%20of\%20US\%20sanctions.pdf (r) رقية عواشرية " حماية المدنيين والأعيان المدنية فى المنازعات الملسلحة غير الدولية " رسلالة

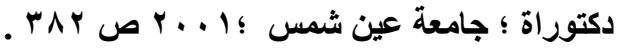


لإجبارها على انتهاج سلوك معين فى إطار ما تفرضه السياسة الخارجية الدولية

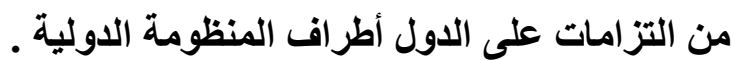

r- تدبير دولى قسرى :- ذلك أنها شكل من أشكل القسر أوالجبر يكون أقل عدوانية

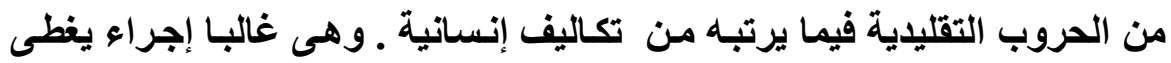

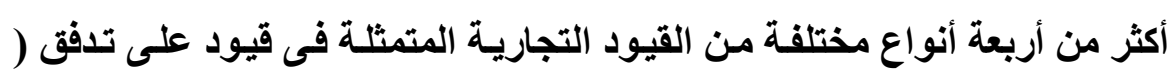
البضائع ؛ الخدمات ؛ الأمو ال ؛ الرقابة على الأسواق ) ( ).

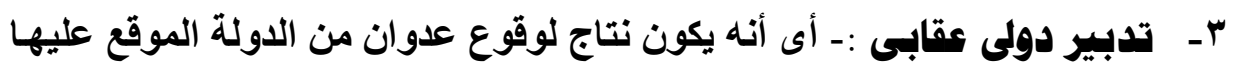

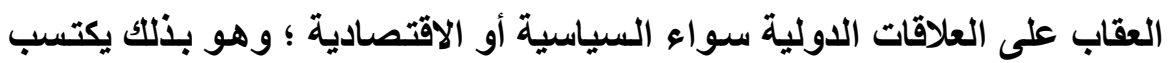
صفة المشروعية لكونه يمثل رد فعل لتصرف مخل بالنسق الدولى . ومن ثم ترتيبا على مـا سبق نجد أن العقوبـات الاقتصادية عبارة عن مرحلة

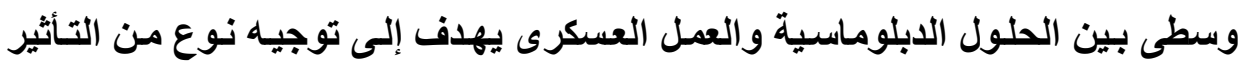

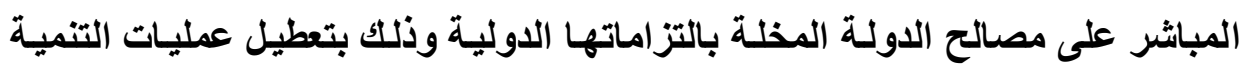

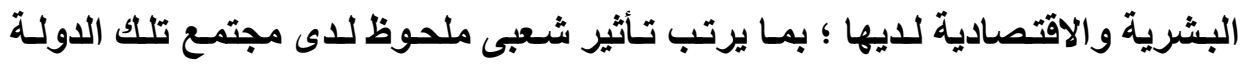

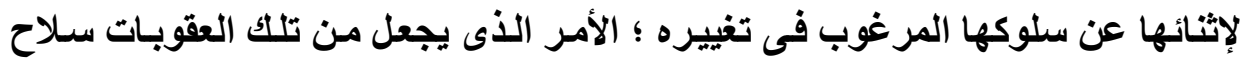
متثعب الآقات ذو خلفيات و انعكاسات وغير محدود التذاعيات .

ثانيًا :- أهداف العقوبات الاقتصادية الدولية

تتعدد الأهداف مـن وراء فرض العقوبـات الاقتصادية الاوليـة لتنطى مختلف أبعاد السياسة الخارجية للاول الغربية ومصالحها الاولية ؛ تلكك الأهداف تتمثل بايجاز

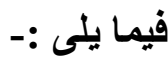

(1) هويدا محمــ عبد المنعم ؛ العقوبـات الدوليـة وأثرهـا على حقوق الإنسان ؛ مهيب للطباعـة ؛

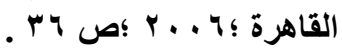


1- منع انتثار الأسلحة النووية وايقاف برامجها فى الدولة المستهدفة .

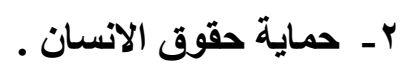

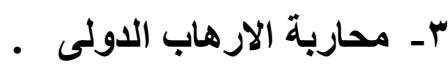

ــ ـ تحقيق عدم الاستقرار فى الدول المستهـفة بالعقوبات .

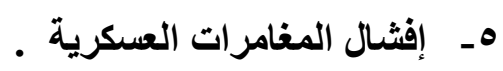

צ- الصراع الإيدولوجى مع الدول المستهدفة .

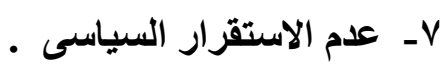

ثالثا:- أنواع العقوبات الاقتصادية (1):-

تنقسم العقوبات الاقتصادية الدولية للأنواع التالية :-

\section{1- أ عقوبات تجارية واستثمارية :-}

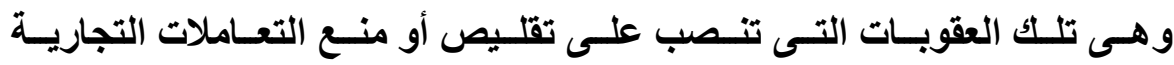
والاستثمارية المؤثرة فى المسار الاقتصادى للاولة المستهلفة ؛ كأن تعتمد مثّلا

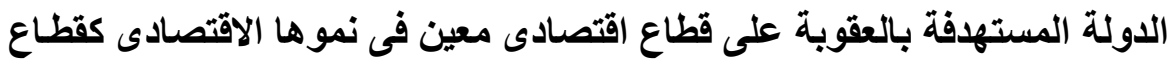

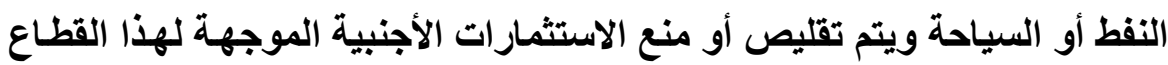

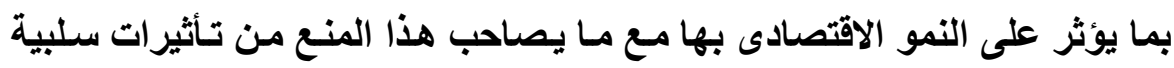
على كافة مناحى الحياة الاقتصادية فى الدولة المستهلفة بالعقوبات ومثالنا فى ذلك

( (1) ينطلق التوصيف الكلاسيكى لأنماط العقوبات الاقتصادية من أنها تعنى تقليص المبادلات الاقتصادية

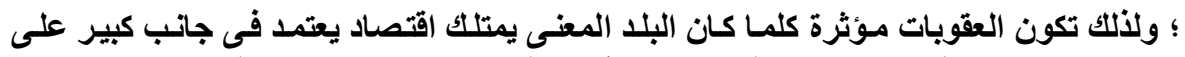

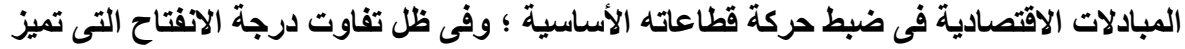

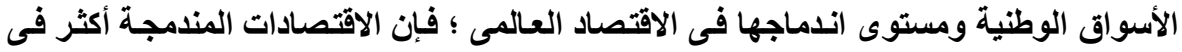

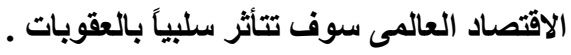


هو فرض حصار على التعاملات والاستثمارات النفطية فى ايران حيث تم فرض فئ حصار بحرى يمنع تصدير النفط ويحظر الاستثمار ات فى قطاع النفط مـع مـا تحتله تلك السلعة من مكانة فى الاقتصاد الايرانى حيث تمثل سلعة التصدير الأولى بإيران

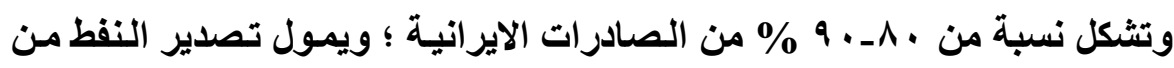

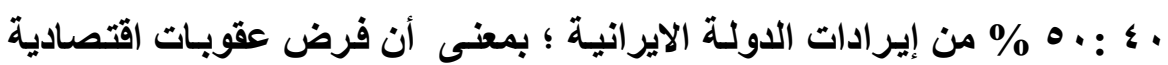
على ايران فى هذا السياق سيؤدى إلى تأثيرات شاملة على كيان ايران الاقتصادى.

r- العقوبات المالية :-

هناك نوع آخر من العقوبـات الاقتصادية وهى العقوبـات الماليـة وهى تلك التى

تستهرف مصالح الثرائح التجارية والصناعية العليا فى الدولة المستهدفة ومثالها :- أن يتم تجميد الودائع الحكومية وودائع الشركات والأفراد الذين يحملون جنسية

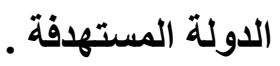

- عرقلة نفاذ الاستثمارات إلى ذات الدولة ركناً هاماً من أركان العقوبات المالية . - وضع شروط تعجيزيـة فيمـا يتعلق بإعادة جدولة الديون المستحقة على البلـ

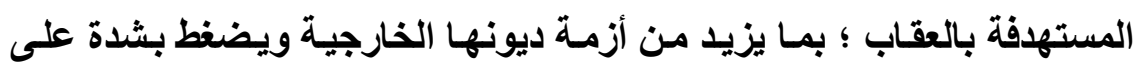

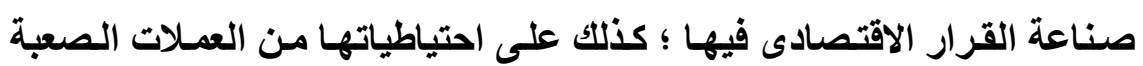
التى سوف تستهلك فى دفع الفوائد والأقساط لسداد ديونها الخارجية . - ايقاف الدول الصناعية لقروض التصدير(') التى تمنحها لشركاتها الوطنية فى حال كانت الصادرات متجهة للاولة المستهدفة بالعقاب .

(1) هى تلك القروض التى تمثل تسهيلات تقدمها الدول لثركاتها الوطنية لتنشيط الصادرات فى صورة

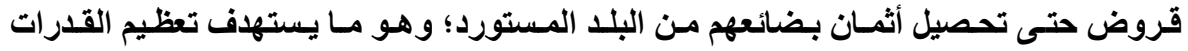

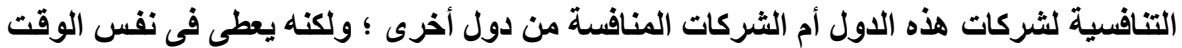

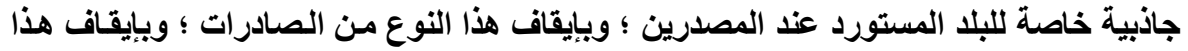
$=$ 
- وتتضمن حزمة هذا النوع من العقوبات أيضاً رفع العملة الوطنيـة للبلد المعاقب

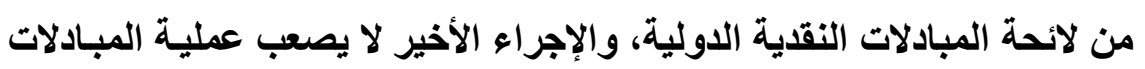
التجارية بشدة فقط، ولكنه يمس أيضاً بسمعتها الاقتصادية الدولية.

جدير بالأكر أنه وعلى النقيض من العقوبـات التجارية والاستثمارية يتميز هذا

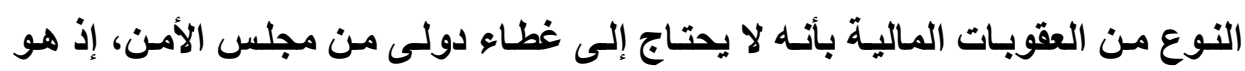

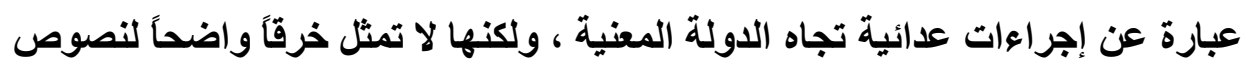

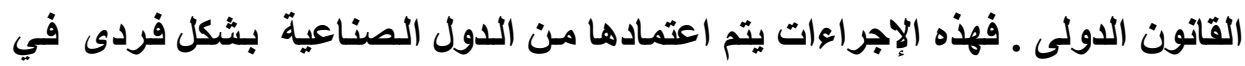
عمليات متكررة ودورية ، للضغط بأحدهاعلى صناع القرار في دول العالم الثالث بغية

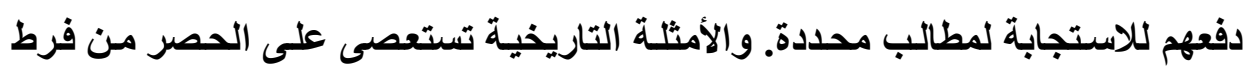
شيوعها في العلاقات الدولية، ولكن الجديد هنا هو ربط هذه الإجراعات كلها ومعظمها

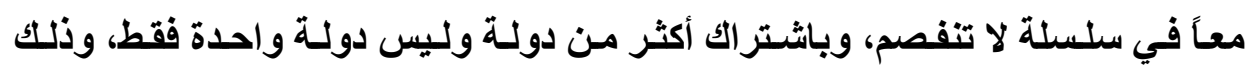
لجعلها بمثابة عقوبات دولية ذات إطار تنسيقى جمعى أكثر تأثيراً.

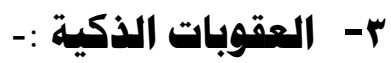

ويستهدف هذا النوع من العقوبات بالأساس قطاعات النخبة في البلا المعنى عن

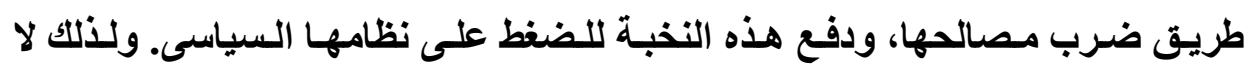

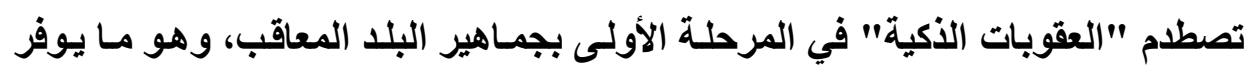

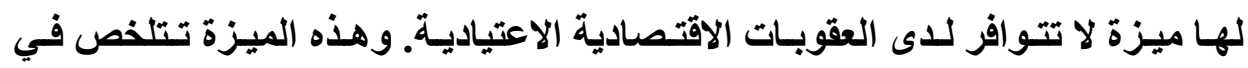
الحيلولة دون استثمار النظام للعقوبات الاقتصادية، وتحويلها إلى أداة لربط الجمـاهير

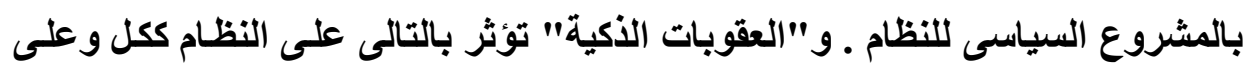

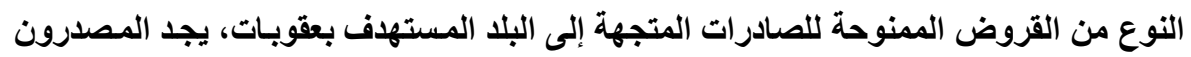

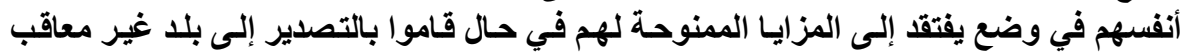




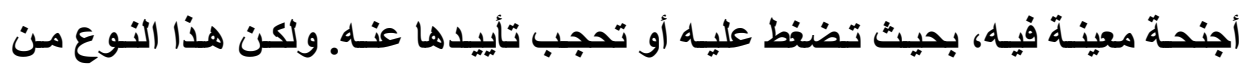

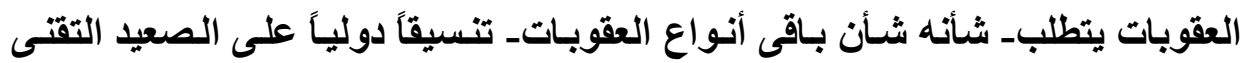

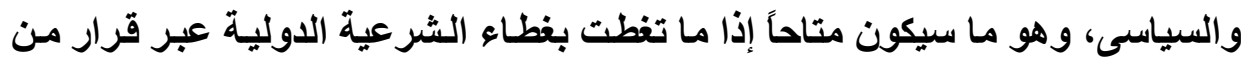

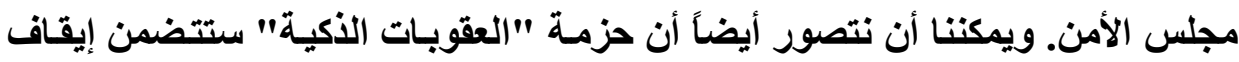

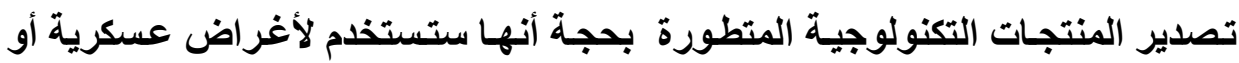
نوويـة، مثـال ذلكت الحظر الذى فرضـه العـالم الغربـى على دول الكتلـة الشرقية إبـان الحرب الباردة. ومروراً بحظر هبوط الطائرات المدنية للاولية المستهذفة في مطارات العالم المختلفة والتضييق على خطوط ملاحتها البحرية. وفى السياق نفسه يمكن تصور

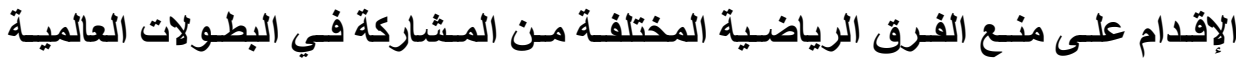

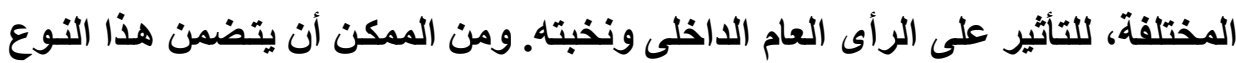

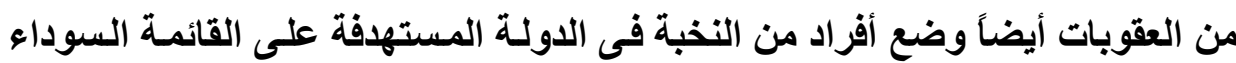

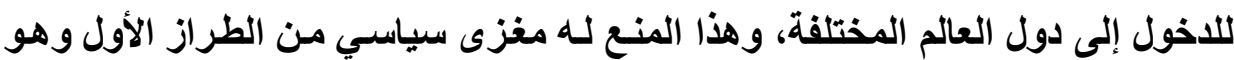
إجبار الدولة المستهذفة بالعقاب على تغيير سياساتها المتسبية في عزلتها الدولية.

\section{رابعًا :- صور ( أطر ) العقوبات الاقتصادية الدولية}

هناك العديد من الصور التى ثُفرض فى إطارها العقوبات الاقتصادية الدولية منها

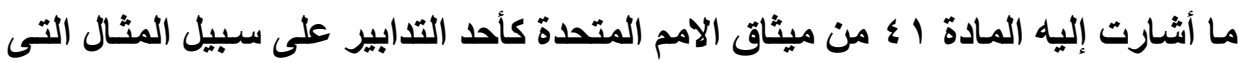

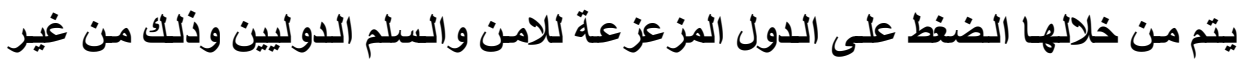
أساليب الضغط العسكرية ؛ ومنها مـا أوجدته طبيعة الظروف وطبيعة الدولية المرسلة للعقاب والدولة المستهدفة به ؛ تتلك الصور هى ما سنحاول أن نذكر بعضها على سبيل

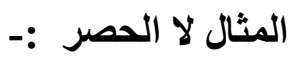

- - - معاملة الاقتصادية بالمثل

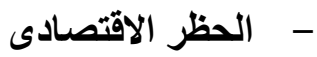




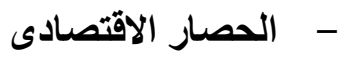 \\ - - المقاطعة الاقتصادية ( ) -}

يُضاف إلى ذلك أن هناك عدد من التدابير المتممـة التى تلجـأ لها الدول مرسـلة العقاب لإحكام الاطار الخانق للعقوبات الاقتصادية لإتيان نتائج ايجابية سريعة وملموسة لهذه العقوبات وتشتهدف تلك التدابير المتممة القضاء على محاولات إختراق العقوبـات المفروضة على الدولة التي ارتكبت الفعل غير المشروع و ضمان عدم التعامل المباشر

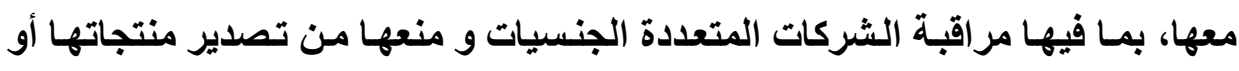

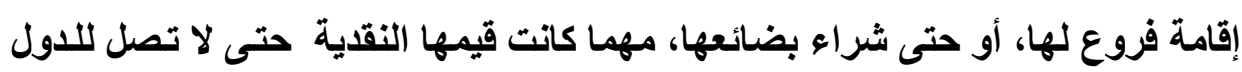

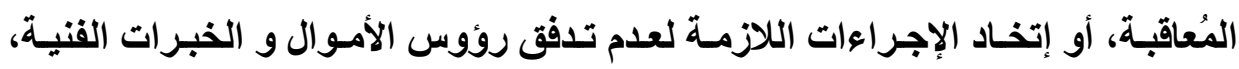

\section{ويكون ذلك فى السياق التالى :- \\ ا - نظام القوائم السوداء:}

و يعنـي إدراج أســاء الأشـخاص أو الشركات الـذين لهـم علاقـات مـع الدوبـة المعتديـة في قوائم خاصـة تعرف بـالقوائم السوداء، و يترتب عن ذلك إعتبـار هؤلاء

(1) لبيان المقصود بصور العقوبات الاقتصادية الدولية يرجى الرجوع للمراجع التالية :-

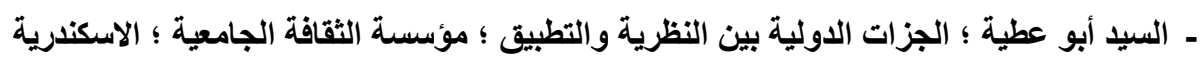
ـ رقيـة عواثـرية " حمايـة المدنيين والأعيان المدنيـة فى المنازعـات الملسلحة غير الدوليـة "

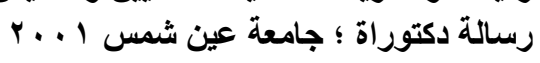
ـ عمر سعد الله ؛ القانون الدولى لحل النزاعات ؛ دار هومـة للطباعة والنشر والتوزيع ؛ الجزائر Y... ـ فاتتة عبد العـال أحمد ؛ العقوبـات الدولية الاقتصادية ؛ دار النهضة العربية ؛ القاهرة ؛ الطبعة

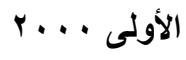


الأثخاص أو الثركات في حكم الدولة المعتدية، و بالتالي تطبيق كل إجراءات المقاطعة عليهم . 1 إن

ويستهذف هذا النظام التأثير على الدول المحايدة بالضغط عليها اقتصاديا، و

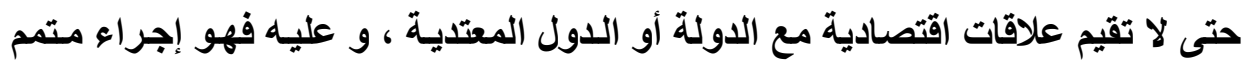

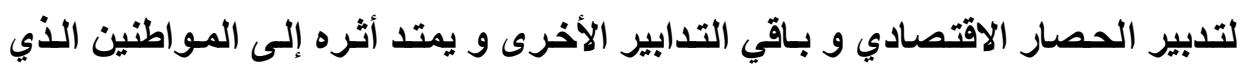

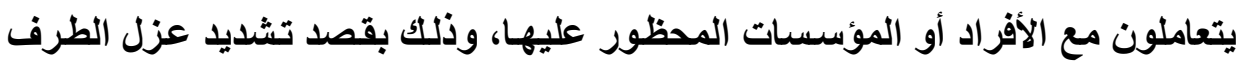
المُعاقب ، و الحيلولة دون حصوله، على المواد الخام و السلع الاستراتيجية.

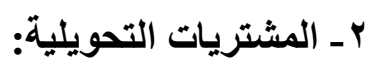

يقصد بالمشتريات التحويلية، شراء المواد الإستراتيجية من الدول المحايدة ، و

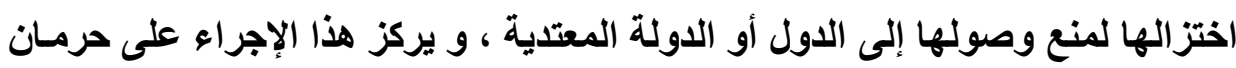

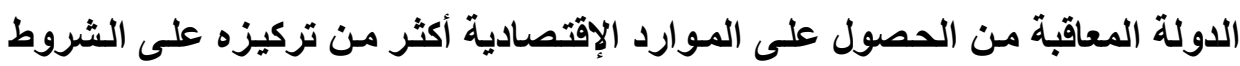

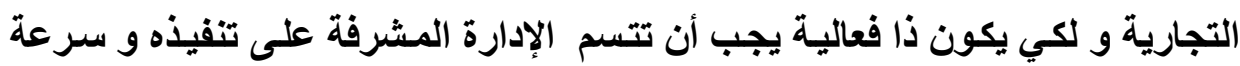
إجراءاتها بالكفاءة ، وأن تكون الدول المنفذة لله على استعداد للتضحية بمصالحها

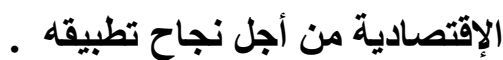

جدير بالذكر أن هناكك العلديد مـن اللدول فى العقود الثلاثة الماضية خضعت

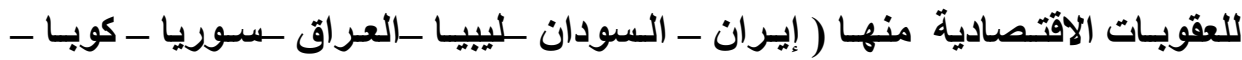

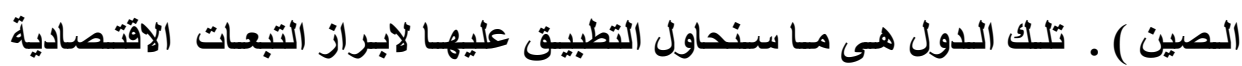
و الاجتماعية للعقوبات الاقتصادية . 


\section{الفصل الأول}

\section{الاثار الاقتصادية للعقوبات الاقتصادية}

تتـاخل الاثـار الاقتصادية والاجتمـاعيـة مفصلياً مـع الاثـار السياسية للعقوبـات الاقتصادية ؛ ويظهر مضمون ذلك فى أن العقوبات تستهـف إلحاق خلل بنيوى بتوازن الاقتصاد الكلى للاولة المستهدفة بتلك العقوبـات إذ تؤدى الى (عجز الموازنة ـ عجز

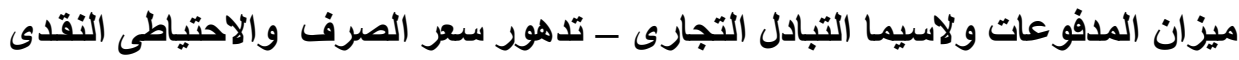

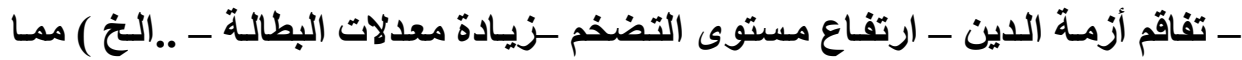

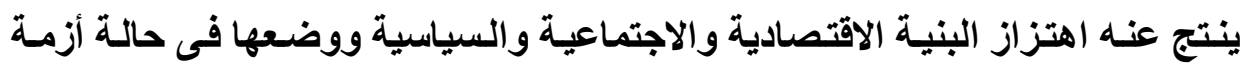
هيكلية ؛ حيث أن توازن الاقتصاد الكلى فى أى بلد ليس سـوى تعبير عن حالـة من

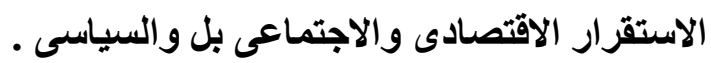

هذا ويتوقف الاثر الاقتصادى للعقوبـات الاقتصاديةعلى حجم الترابط الامـامى والخلفى للاولة المستهرفة بالعقاب مع حلقات التجارة الدولية ؛ فكلما كاتت تلك الدولة الاتلة تعتمد فى نشاطاتها الاقتصادية على حركة التجارة الدولية تصديرا واستير اداً كلما كاتت

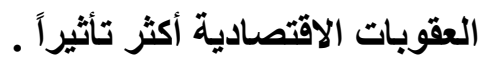

كذلك يتوقف الاثر المباشر للعقوبـات الاقتصادية الدوليـة على كونها عقوبـات اقتصادية من المجتمع الدولى ككل ؛ أم أنها عقوبات انفرادية من إحدى الدول تجاهريا . إذ أنه لو كانت العقوبات من قبل المجتمع الدولى تجاهها كلمـا كاتت أكثر تأثيراً ؛ فى حين إذا كانت تلك العقوبات انفرادية فتتوقف على حجم النشاط التجارى المتبـادل بين الاولة المستهدفة بالعقوبات والدولة المرسلة للعقوبات . 


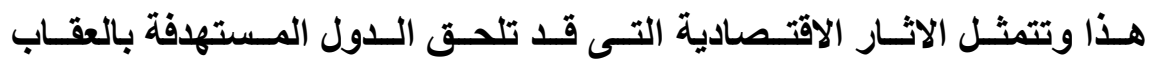

$$
\text { فيما يلى :- }
$$

أولا :- تأثير العقوبات الاقتصادية على القطاعات الاقتصادية الرائدة :-

تستهدف العقوبات الاقتصادية الدولية أياً كانت مبرراتها شل المصادر الرئيسية

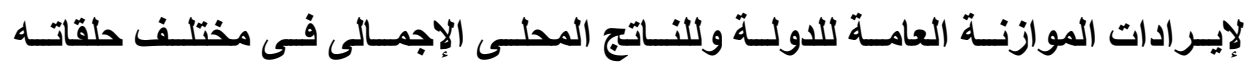
الاستثمارية والتسويقية المباثرة أو غير المباشرة وذلك فى الدولة المستهدفة بالعقاب الابه وذلك لإرغامها على تنفيذ مطالبات الجهة أو الجهات المرسـلة بالعقاب ـ وهو الأمـر الذى يبدو جلياً فى أن معظم التدابير الاقتصادية التى فُرضت على العراق فى. أعقاب مغامراتها العسكرية ومحاولتها احتلال الكويت فى بدايـة التسعينيات من القرن الماضى وحتى سقوط نظام الرئيس صدام حسين استهدفت القطاع الاقتصادى

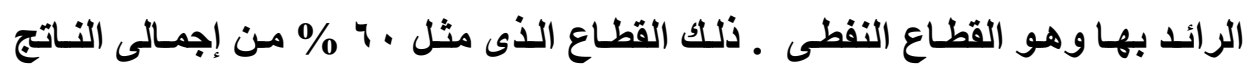

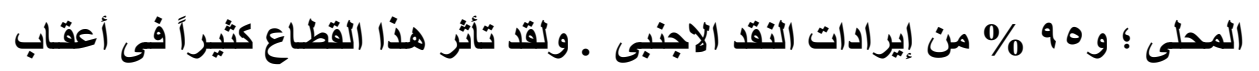
فترة الحصار الاقتصادى وإقرار برنامج النفط مقابل الغذاء فبرغم أن كميـة النفط التي واتي يصدرها العراق بلغت أعلى معدل لها منذ عام 199 1، إلا أن العائدات ظلت غير كافية بسبب الارتباط السلبي بين أسعار النفط المنخفضة والتأخير في الحصول على قطع الغيار اللازمة والتهالك العام للبنية التحتية لصناعة النفط ؛ والسقف الذارئ والى تم اقراره

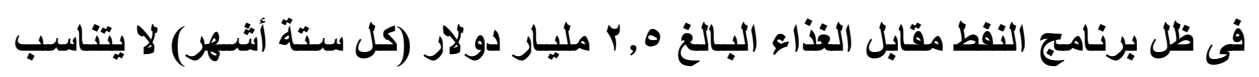

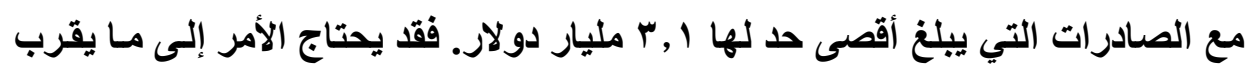

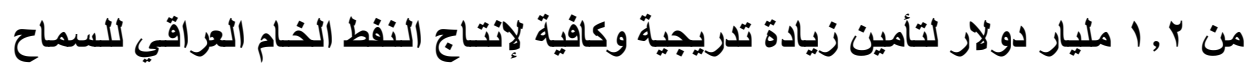

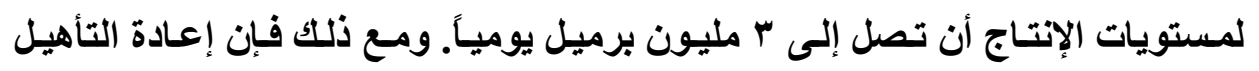
الكامل لصناعة . 


\section{النفط في العراق قد تختاج إلى عدة هليارات هن الدولارات"'.}

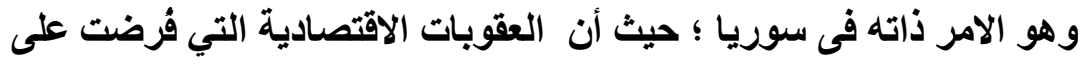

سوريا من قبل كل من الولايات المتحدة الأمريكية، الاتحـاد الأوربي والجامعة العربية، كان لها أثرها السلبي على الاقتصاد السوري. فالحظر النفطي تسبب بخسارة عائدات

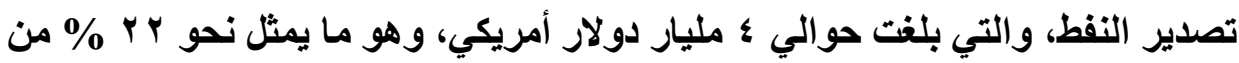

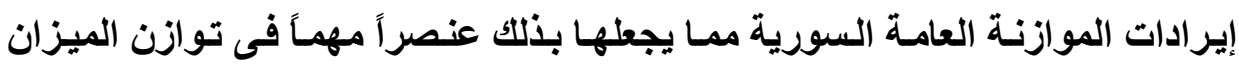

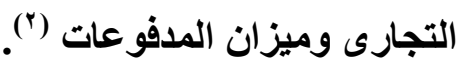

فضلا عن ذلك فقد رتبت العقوبـات المفروضـة على الاقتصاد السورى وإحكام الخناق على القطاع النفطى الى توقف حلقات الاستثمار والتجديد والانتاج والتسويق ؛ بل وتلاشت الصادرات السورية من النفط الخـام تقريباً ؛ بسبب تراجع حجم الاتتاج ؛ وصعوبة العثور على مستوردين أو موردين للمشتقات لانهم سيعرضون بذألك أنفسهم

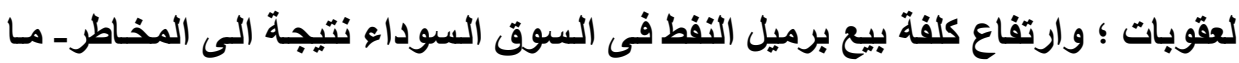

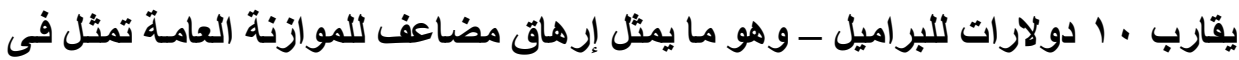
تحميلها أعباء مضاعفة لسد الفجوة بسبب انحسار العائد من الصادرات النفية ؛ ومن ثم ارتفاع أعباء تمويل حاجتها من المشتقات وتحديداً الديزل والوقود لمحطات الكهرباء والبنزين والغاز تلك الحاجـات الضرورية لمتطلبات الحياة الطبيعية للمواطن السورى

http://www.aljazeera.net/portal

(r) نبيل مرزوق " العقوبات الاقتصادية :- خنق بطى للنظام السورى " ؛ مركز الجزيرة للاراسات ؛

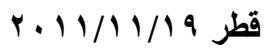

http://studies.aljazeera.net/reports/2011/11/2011111910249163525.htm 
وكذا النشاط الاقتصادى فى سوريا(') ؛ وهو الامر الذى سـاهم فى تقليص النشاطات

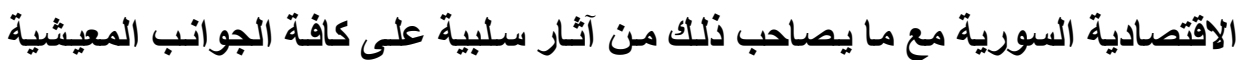
للمواطن السورى .

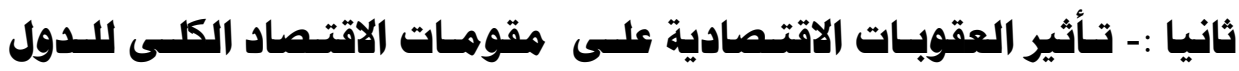

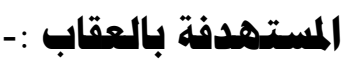

يستتبع التأثير على القطاعات الاقتصادية الرائدة فى الاقتصاد القومى ؛ عدد من

التأثيرات السلبية على مقومات ومؤشرات الاقتصاد الكلى وذلك على النحو التالى :-

ا - انغفاض الناتج المهلى الاجمالى :-

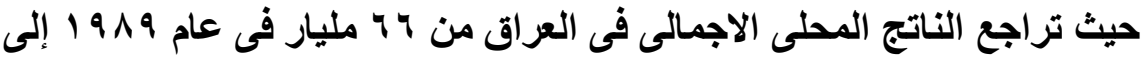

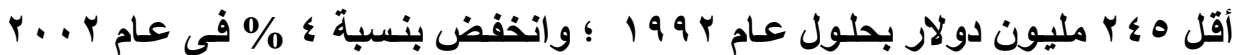

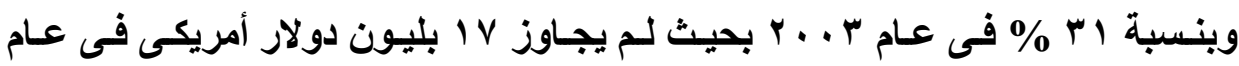
(r) r...r

وفى سـوريا تسبيت العقوبـات المفروضـة عليهـا فى إلحساق الاقتصاد السوري

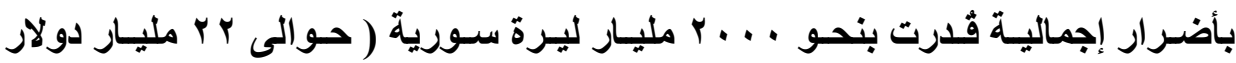

(1) جدير بالذكر أن تقيرات الموازنة السورية تثير إلى أن إيرادات بيع الخام النفطى السورى الثقيل

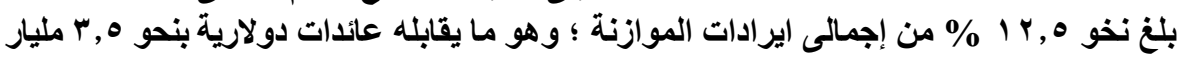

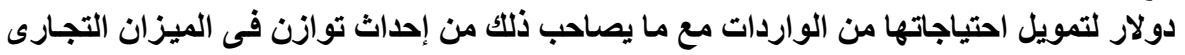

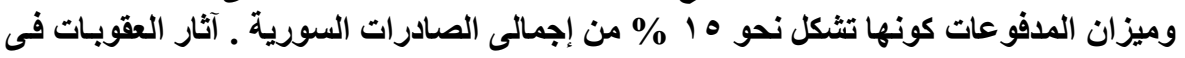

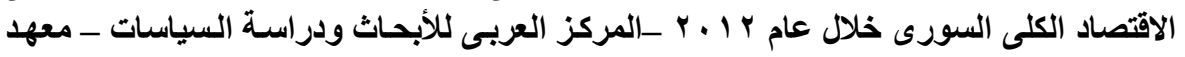

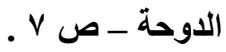

(2) Arya Neil, «Economic sanctions: the kinder, gentler alternative?». www.informaworld.com/smpp/.../content $\sim \mathrm{db}=$ all $\sim$ content $=\mathbf{a} 790526054$., p. 9 
أمريكى ) وهو ما يمثل هـ \% من النـاتج المحلى الإجمـالى لعـام • 1 . ب بعد احتساب

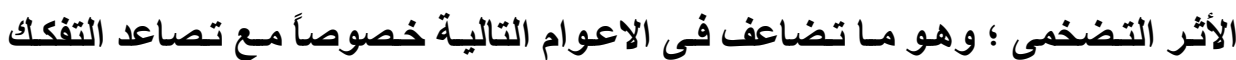
(السورى (') (1) (1)

\section{r- انففاض نصيب الفرد هن الدخل القوهى :-}

يُقاس متوسط نصيب القرد من الدخل القومى = الدخل القومى / عدد السكان .

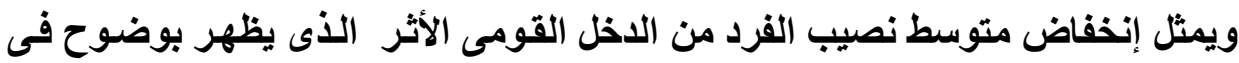
الاول المعاقبه اقتصادياً بعقوبات دولية ؛ يث تراجع نصيب الفرد العراقى من الدخل القومى بحيث لم يزد عن . r دولار سنوياً ؛ فى حين أن البنك الدولى قد قدره بنحو

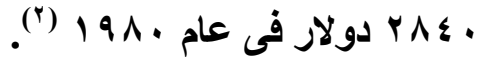

\section{r- انهيار القوة الشرائية للعمملات الملية :-}

إذ انهارت القوة الثرائية للاينار العراقى ؛ حيث كان سـر التعـادل قبل الحصار الاقتصادى (ع دينار لكل دولار أمريكى ) وذلك فى أوائل عام ، 99 أل ؛ أما بعد العقوبات فقد انهار الى أن وصل فى أثناء تطبيق برنامج النفط مقابل الغذاء إلى ( • ؛ ؛ دينار لكل دولار أمريكى )عام . . . ؟ ؛ وهو الأمر الذى أدى بـوره إلى انهيار القوة الشرائية وازدياد نسبة الفقر (") وفى سـوريا شكلت العقوبـات الماليـة عائقةً إضـافيًا أمسام التجارة، إذ أنها عقدات

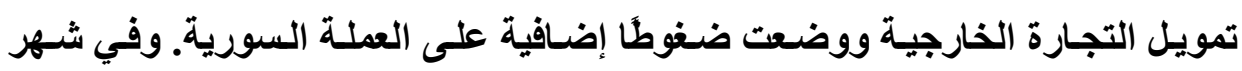

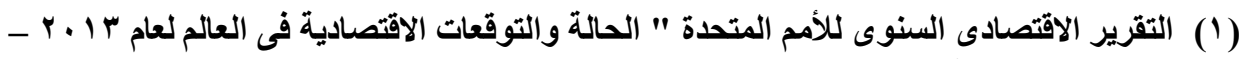

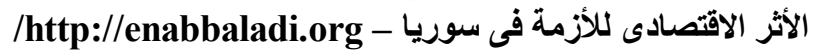

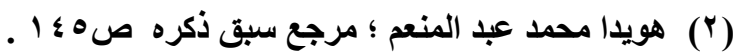

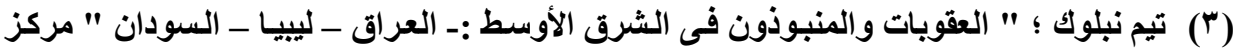

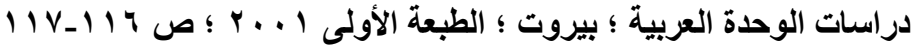




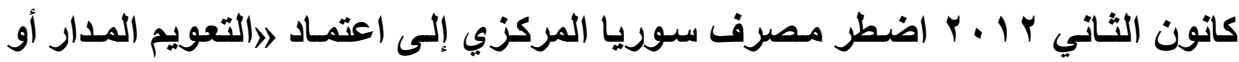
المحكومه لسعر صرف العملة الوطنية، مما سمح بتخفيض قيمة العملة السورية بـأكثر

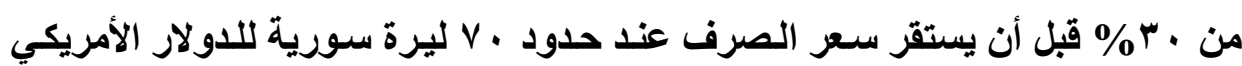

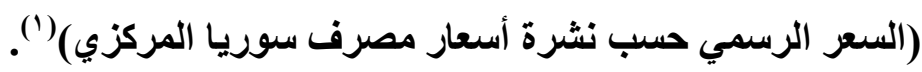
وفى إيـران فقــ الريـال الايرانسى نـصف قيمتهـه مقابـل العمـلات الأخرى فـى عـام

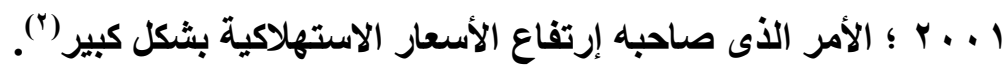
هذا فى حين كان نتاج العقوبات الاقتصادية التى تفرضها الولايات المتحدة على زيمبابوى أنه فى 9 . . ب علقت الحكومة الزيمبابوية استخدام الدولار الزيمبابوى لأنـه أصبح لا قيمة له ؛ وأعلن رسمياً عن قيام الدولة باستخدام " الدولار الأمريكى والراند

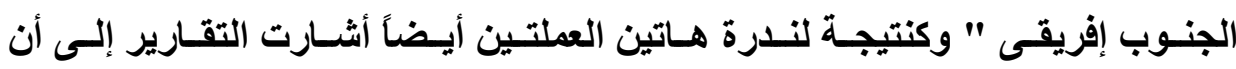
المواطنين الزيمبابويين انخرطوا فى تجارة المقايضة ("). צ- ارتفاع همدلات التضفم :-

إذ أن أحد الاثار السلبية على الحالـة الاقتصادية الكلية ارتفاع معدلات التضخم

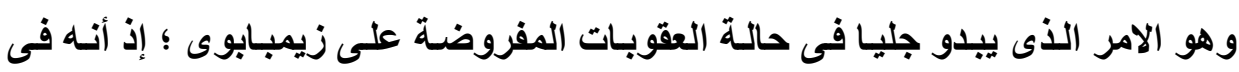

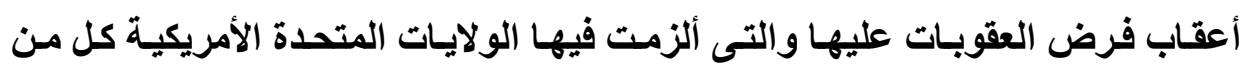

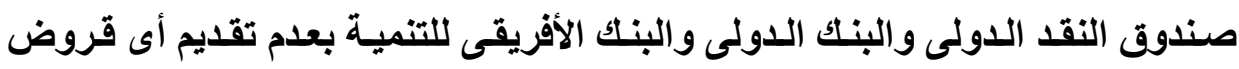

$$
\begin{aligned}
& \text { (1) التقريز الاقتصادى السنوى للأمم المتحدة ؛ مرجع سبق ذكره . }
\end{aligned}
$$

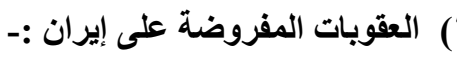

http://www.marefa.org/index.php?title

(3) Chingono Heather, "Zimbabwe sanctions: An analysis of the "Lingo" guiding the perceptions of the sanctioners and the sanctionees", African Journal of Political Science and International Relations, Vol. 4, February 2010. Pp 70-71 


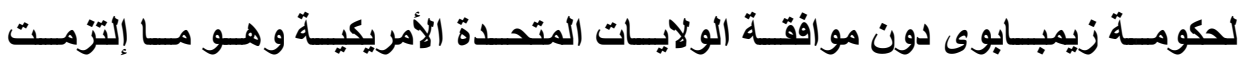

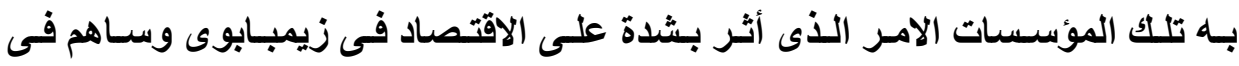
ارتفـاع مستويات التضخم بها لتصبح واحدة مسن أكبر حسالات التضخم فـى العـالم ؛

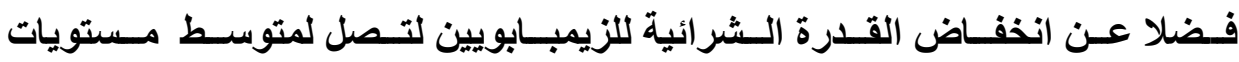
عام 1904 (') (190)

وفى سـوريا على الـرغم مـن الاجراءات التى بـذلتها الحكومـة المحليـة لتقليل

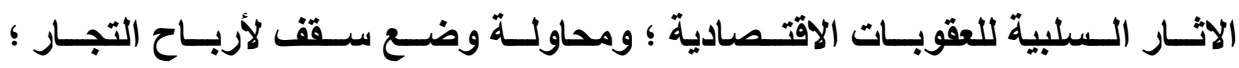

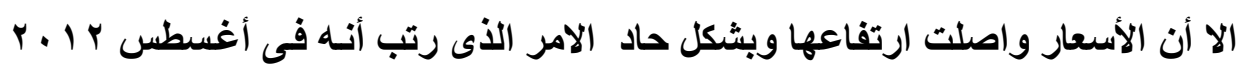

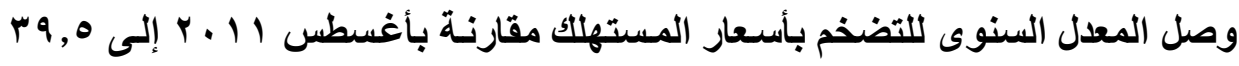
. ${ }^{(\top)} \%$

\section{0- ارتفاع هؤشرات البطالة :-}

يُمثل ارتفاع مؤشر البطالة أحد المظاهر السلبية للعقوبـات الاقتصادية الدولية ؛

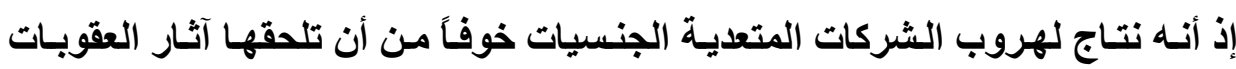

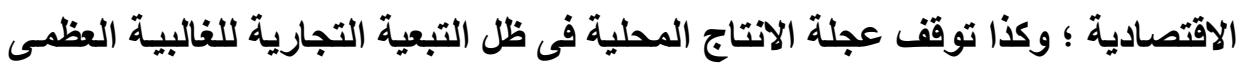

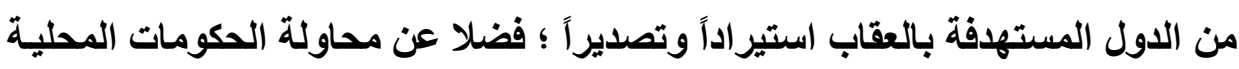

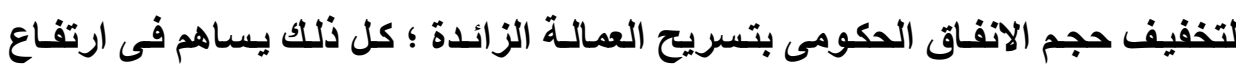
مؤشرات البطالة فى الدول المستهدفة بالعقوبات الاقتصادية وهو ما يبدو جلياً فى :-

(1) Hani Mansourian, " The Human Cost of Sanctions on Iran ", 03November 2010

,Disponible sur le site internet:-

http://www.stumbleupon.com/su/2tcxGB/muftah.org/\%3Fp\%3D403

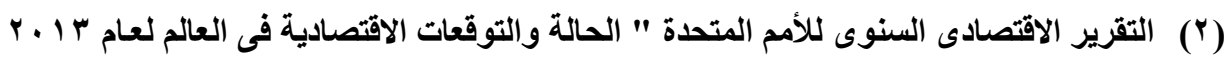

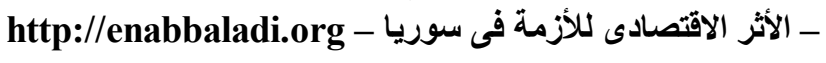


- سوريا :- على الرغم من الاجراعات الحكومية لتلافى الاثار السلبية للعقوبـات الات

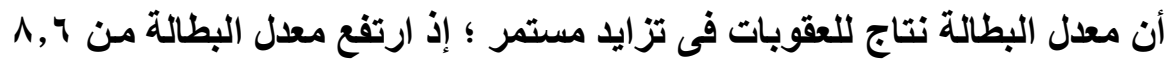

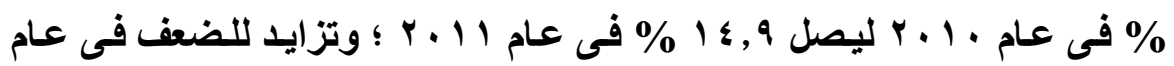

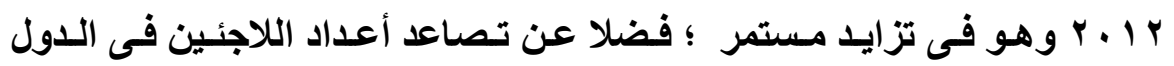

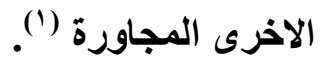

\section{1- تراجع هؤشرات التصدير :-}

لعل أحد الاثار السلبية المصاحبة لفرض العقوبات هو تراجع مؤشرات التصدير

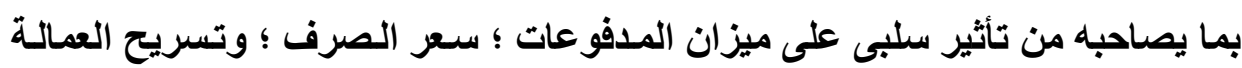

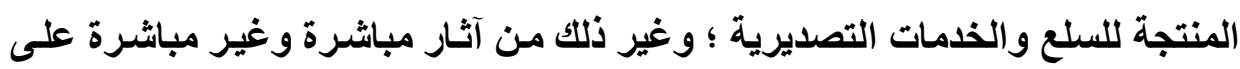

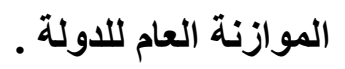

هذا وتثير تقديرات البنك الدولى إلى أن العقوبات الاقتصادية التى فرضت على

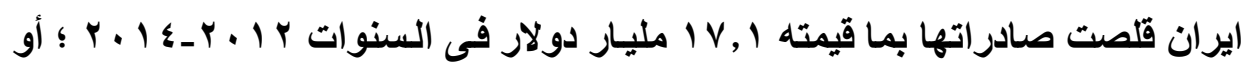

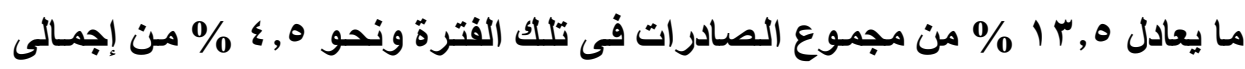

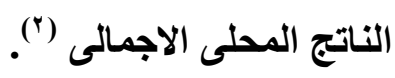
وفى زيمبابوى سـاهم الحظر التصديرى الذّى فرضـه الاتحساد الاوربى عليها فى

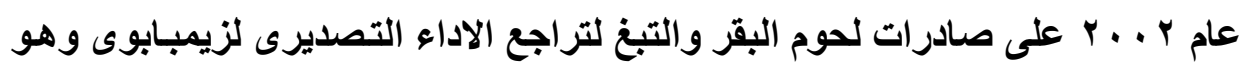

( الت التقرير الاقتصادى السنوى للأمم المتحدة " الحالة والتوقعات الاقتصادية فى العالم لعام ب ا ـ ب ؛ مرجع سبق ذكره . (r) البنك الدولى :- الموجز الفصلى لمنطقة الثرق الاوسط وشمال أفريقيا ؛ يوليو 10 ـ ب ـ الاثار

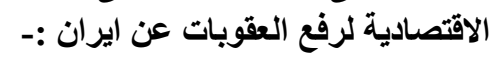

http://www.albankaldawli.org/ar/region/mena 
الامر المهم والحيوى لاستدامة أكبر الاسواق المحلية الامر الذى مثل ضغطا على توافر

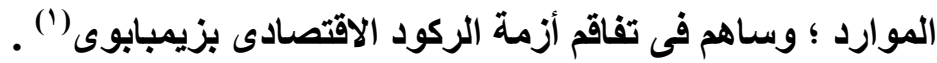

ү- تناقص الاحتياطيات النقدية الاجنبية ؛ واهتراز سعر الصرف :-

فى ظل ما ترتبه العقوبات الاقتصادية من :- فرض حالة من العجز او انعدام التحكم والسيطرة فى الارصدة النقدية المتداولة فى

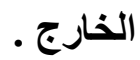

- - تراجـع الايـرادات مـن العمـلات الاجنبيـة المترتبـة على الـصادرات للخـارج التـى

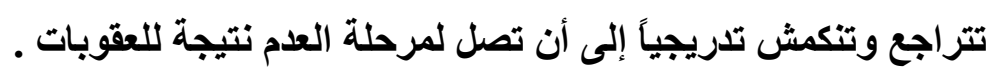

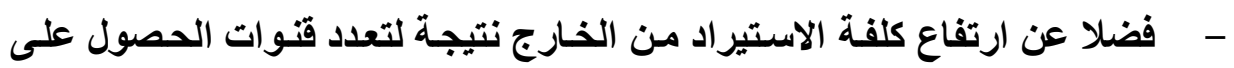

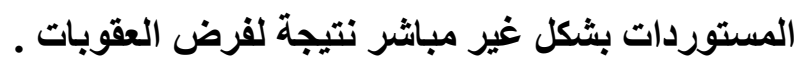

كل هذه العوامل سـاهمت بشكل رئيسى فى تذبذب سعر الصرف وفى الحفاظ على

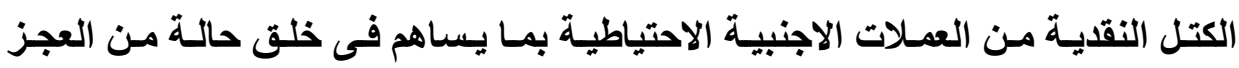
الاقتصادى على توفير الاحتياجات الاساسية للمجتمع . ومثالنا فى ذلك الوضع السورى حيث يبدو أثر تلاشسى الصادرات مـع ضرورة

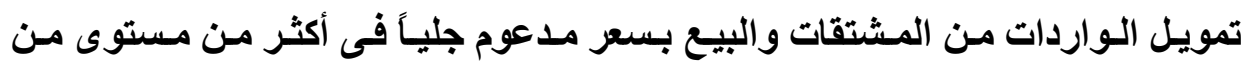

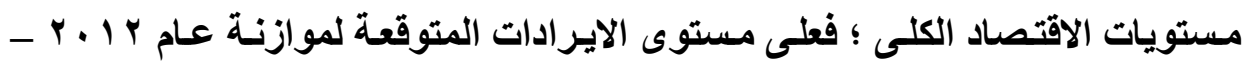
وهو العام الذى يتضح فيه بصفة ملموسة مدى الأثر الفعلى للعقوبات عموماً وفى قطاع

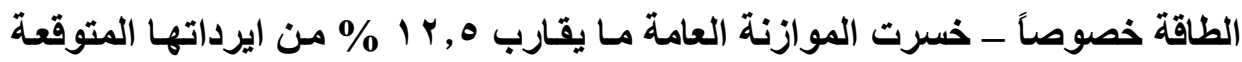

(1) Heather Chingono,op. cit,p . 72. 
فى حال عدم التمكن من بيع النفط فى السوق السوداء (')؛ اذ أصبحت سورياً تعتمد على احتياطياتها مـن العملة الاجنبيـة ممـا ترتب تنـاقص حساد فـى الاحتياطيـات بسبب تمويل واردات المشتقات وتمويل واردات القطاع الخاص من المواد الأولية التى تخضع لرسوم جمركية أقل من 1 \% وهى كتلة كبيرة نسبياً من الحجم الاجمسالى لواردات

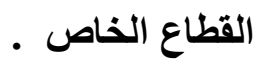

هذا وقد مثل الاعتمـاد المتتالى على الاحتياطيـات من العمـلات الاجنبية مزيـ من

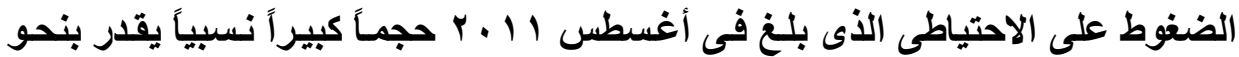

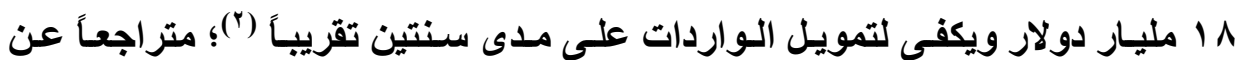

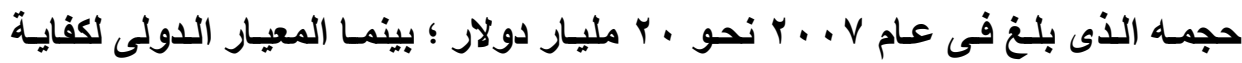
الاحتياطى هو تمويل الورادات لثلاثة شهور (ب). وقد سيل المصرف السورى المركزى من هذا الاحتياطى فى ضوء اضطراب سعر

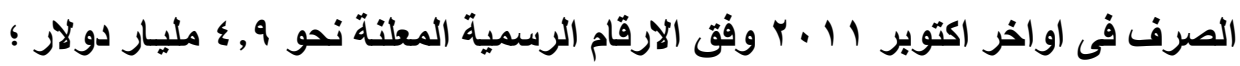

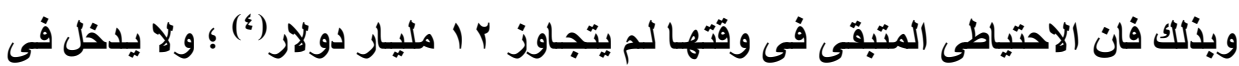
هذا الرقم ما انفقه مصرف سوريا المركزى بأسلوب المزادات لمحاولة لجم تراجع سعر

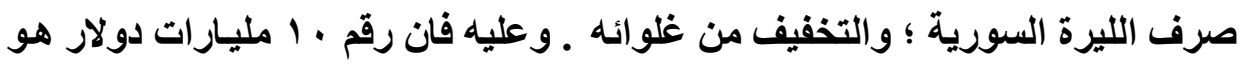

(1) نبيل مرزوق :- " العقوبات الاقتصادية - خنق بطىع للنام السورى " مركز الجزيرة للاراسات ؛

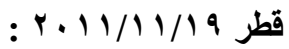
http://studies.aljazeera.net/reports/2011/11/2011111910249163525.htm

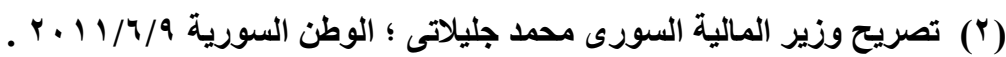

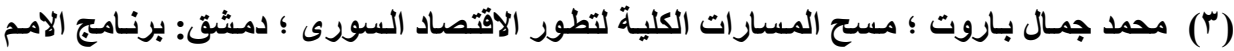

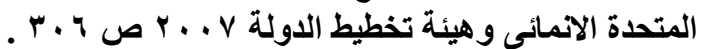

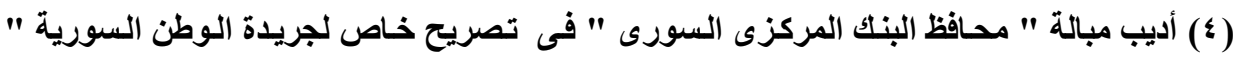

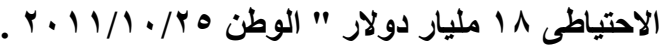


الرقم الواقعى جدا لتقدير الاحتياطى النقدى الاجنبى السورى الذى يقع تحت مخاطر

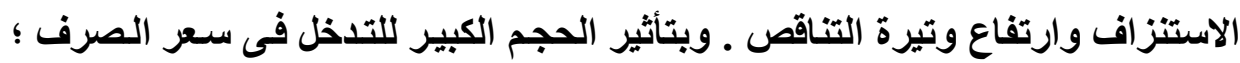

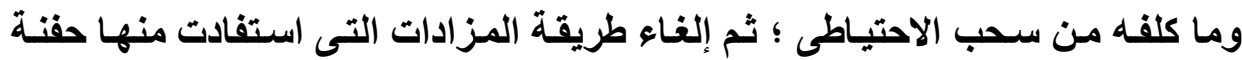
ضئيلة من المزايدين أكثر مما استفاد منه سعر صرف الليرة ـ وتوقف مصرف سوريا

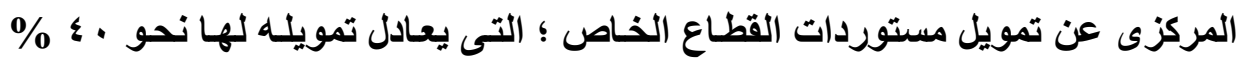

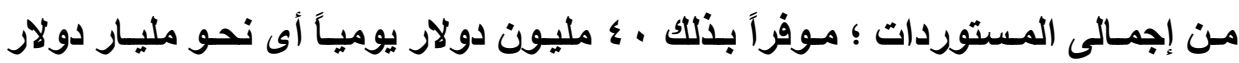
أمريكى شهرياً.

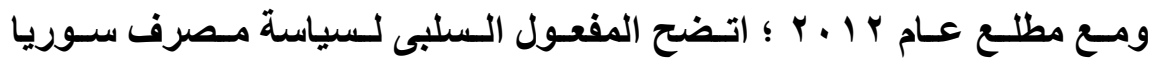
المركزى فى استنزاف احتياطى العملة الاجنبية ؛ وبايـة أثر العقوبـات بصفة ملموسية

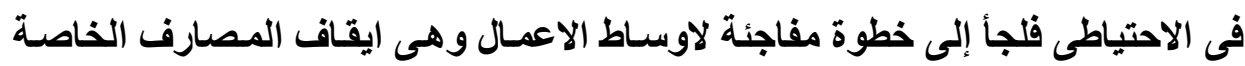

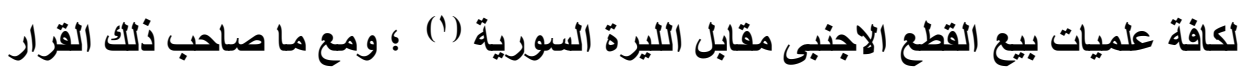

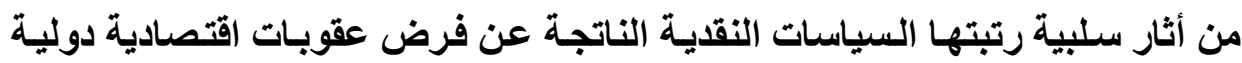

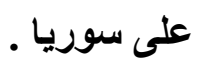

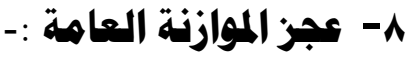

لعل عجز الموازنـة العامـة يمثل سبياً ونتيجة للاثـار الاقتصادية التى ترتبها العقوبات الاقتصادية الدولية على الدول المستهدفة بالعقاب حيث أنه لتراجع موارد العاديا

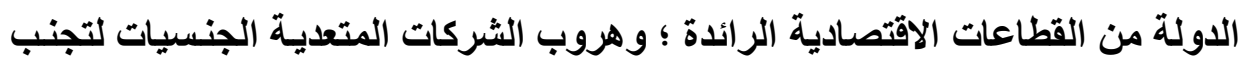

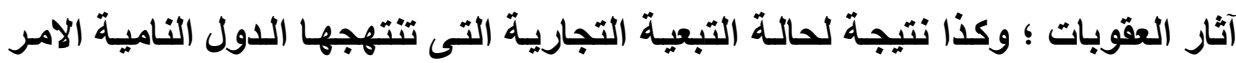

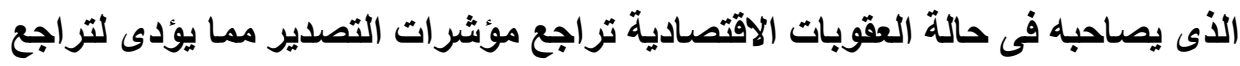

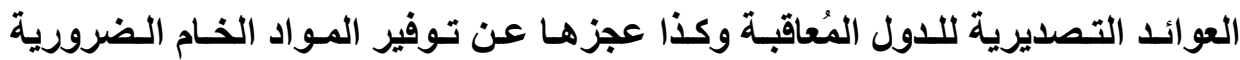

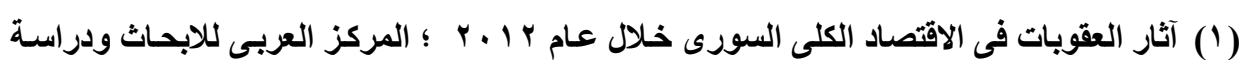

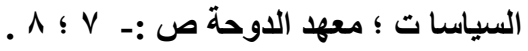


للصناعة المحلية ؛ الامر الذى يصاحبه وقف عجلة الانتاج بمـا يصاحبه من ارتفاع

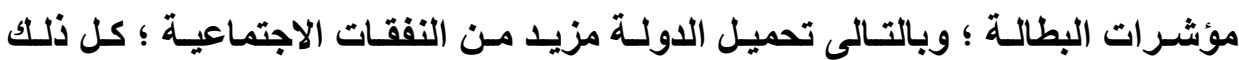

وغيرها من آثار سلبية يساهم فى عجز الموازنة العامة وهو ما يبدو جليا فى :- ايران :- حيث أنه كنتيجة للعقوبـات المفروض عليها فبان العديد من الشركات المتعدية الجنسيات غادرت ايران ؛ وأصبحت الثركات المحلية من القطاع الخاص تجد صعوبة بالغة فى العمل فى بيئة عمل غير مستقرة ؛ والبعض منها أعلن حالة

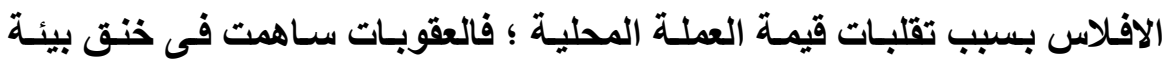

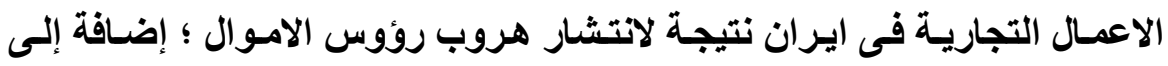

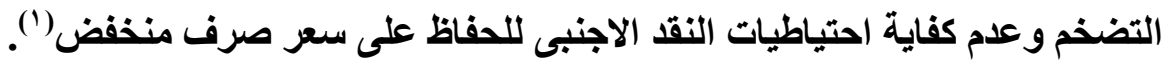
هذه الاثار على المديين القصير والمتوسط أدت لخلق حالة من العجز فى الموازنة العامـة لايران ؛ الامر الذى استتبعه تخفيض الانفـاق الحكومى لتدارك أثر تلك فئك الازمة على المدى الطويل .

9- استمهرار حالة الركود الاقتصادى :-

إن النتيجة الطبيعية لكل الاثار السلبية للعقوبـات الاقتصادية الدولية على الدول المستهدفة بالعقاب هو خلق حالة من الركود الاقتصادى تتمثل فى تراجع معدلات النمو الاقتصادى ؛ وانحسار الانتاج ؛ وضعف مستوى الانتاجية ؛ فضلا عن ارتفاع مؤشرات

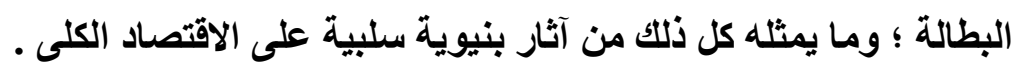
وهو ما يتضح فى سوريا إذ واجهت فى أعقاب فرض العقوبات الاقتصادية تحدياً كبيراً يرتبط بمدى قدرته على تجاوز الأثر التراكمى لتراجع معدل النمو الاقتصادى فى

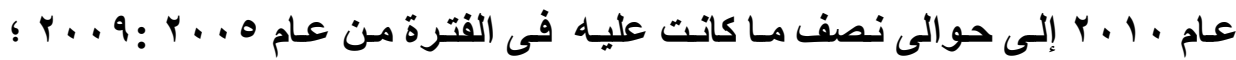

(1) Hani Mansourian, op. cit. 
والركود الاقتصادى أو النمو السالب بمعدلات كبيرة فى عام II I ـ والتى تصاعدات

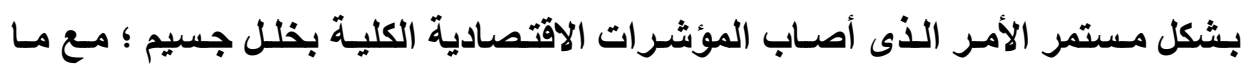

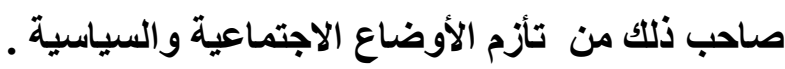

ويبدو ذلك فى عدم القدرة على توليد فرص عمالة جديدة وهو ما يفـاقم البطالة

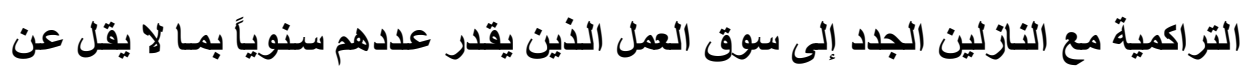

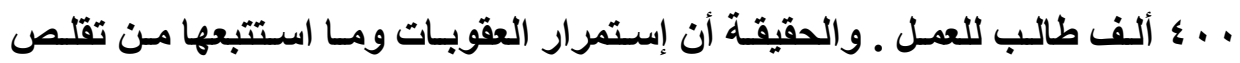

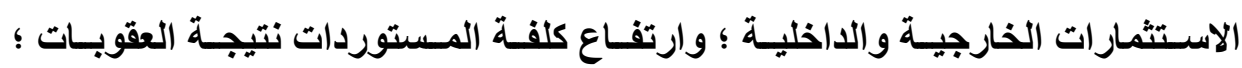
واختلال سعر الصرف والقيود على المصرف التجارى السورى ؛ وعدم وجود منهج للحكومة فى إدارة الأزمة وضع الاقتصاد السورى أمام التحدى الحقيقى للبطالـة والتى

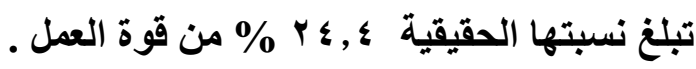
وهو ما يفسر تـأجج الأوضـاع الاقتصادية والاجتماعية ؛ خصوصاً فى المنـاطق

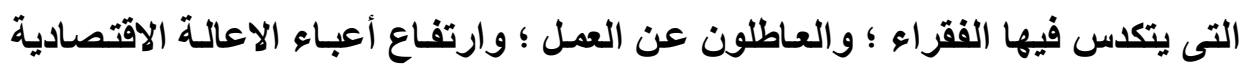
والعمرية الأمر الذى يرتب تنامى كلا من الفقرين المادى والبشرى على حدً سواء ( '). ثالثًاً :- تأثير العقوبات الاقتصادية على مقومات الفقر البشرى :بدايـة قبل التطرق لتأثير العقوبـات على الفقر البشرى فى الدول المستهدفة بالعقوبات ؛ ينبغى علينا توضيح المقصود بالفقر البشرى ؛ والأى ينطوى على :-

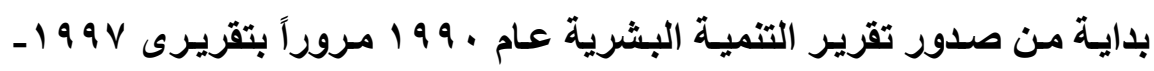

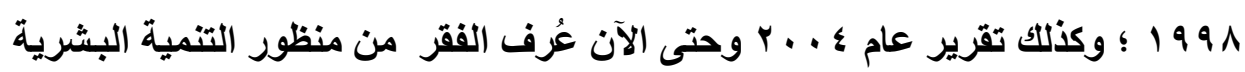


على أنه " انعام الفرص والخيارات الأساسية ذات الأهمية الأساسية للتنمية البثرية ؛

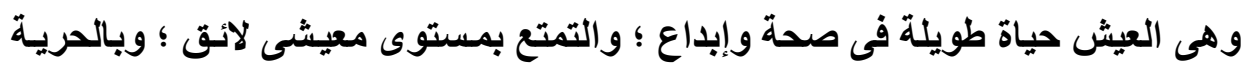

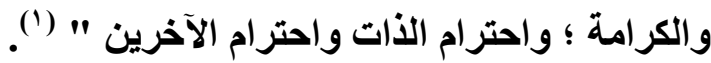

ولتحليل هذا التعريف نجد أن هناك أسلوبين مختلفين فى قياس حجم الفقر وحجم

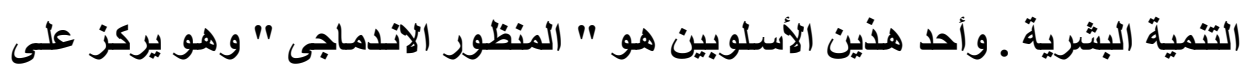

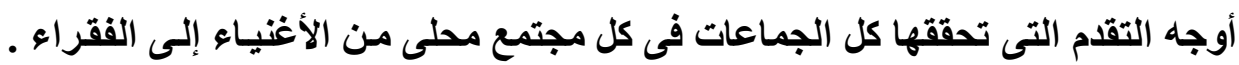
ويقابل هذا الأسلوب وجهة نظر بديلة تتمثل فى " المنظور الحرمسانى " الذى يتم

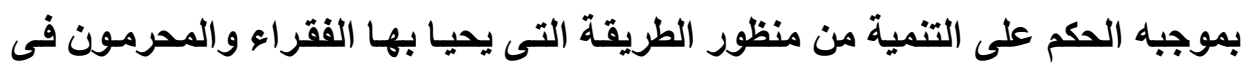

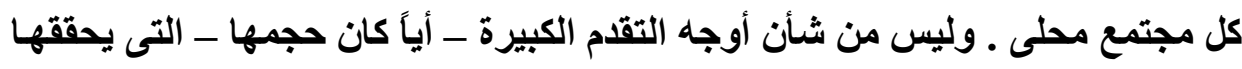

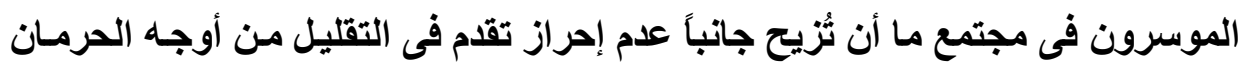

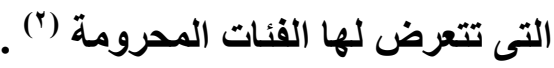

ويربط الفقر البشرى بالنتائج السلبية للعقوبات الاقتصادية المفروضة على الدول

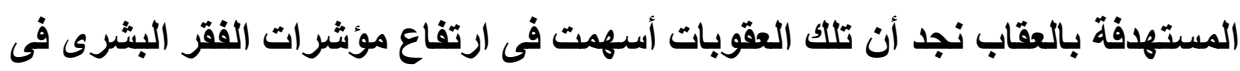
تلك الدول بمعدلات لم يسبق لها مثيل . حيث نجد أن العقوبات الاقتصادية الدولية التى فرضت على العراق فى أعقاب

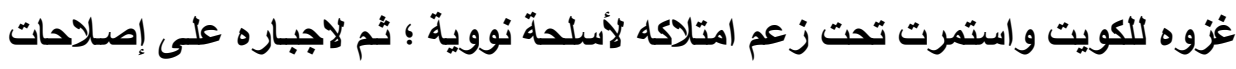
ديمقراطية قد رتبت :-

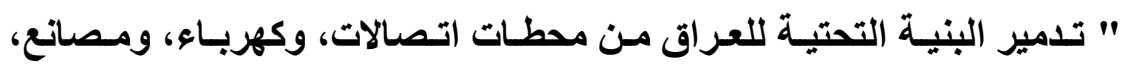

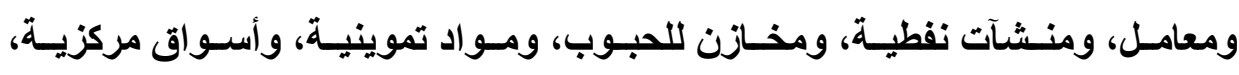

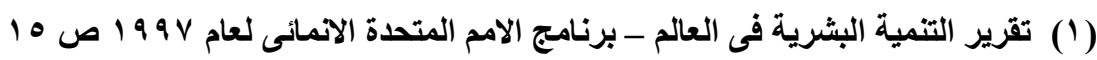

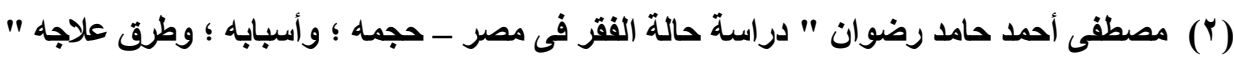

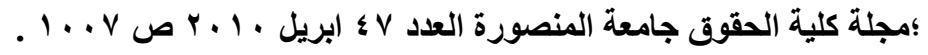


ومحطات ضخ الميـاه، والمنـازل، وحتى الملاجئ التي احتمى فيها المواطنون لم تكن ملاذاً آمناً لهم أمام القصف الصاروخي البري والجوي والبحري المركز على مدى بـ يوماً.

وأدى الحصار إلى نتائج مخيفة في جميع مجالات الحياة العامة الصحية والبيئية والاجتماعية والتربوية والعلمية والاقتصادية ـإذ تعمقت مظاهر التردي والترهل إلى التى الحد الذي أفقد المجتمع العراقي سمات المجتمع المتحضر المتماسك الذي كان عليه قبل غزو الكويت. فنظراً لعدم قدرة الحكومة على تأمين الوظـائف الحكومية وفي القطاعـات الصناعية التي توقفت نتيجة الحصار، فقد تم تسريح ما يقارب ثلثي القوى العاملـة ممـا ساهم في زيادة معدلات البطالة وتمزق العياة العائلية نتيجـة ارتفـاع معدلات الجريمـة،

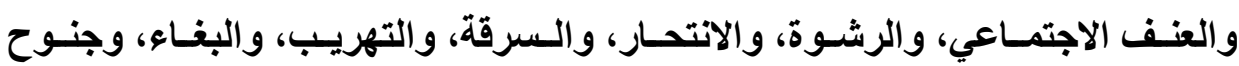
الأحداث، وظواهر اجتماعية أخرى تؤكد الخلل الخطير في بنية المجتمع العراقي. إلى جاتب تـدهور المعاهد التعليميـة في كل المراحل وشيوع ظـاهرة التسرب وانخفاض مستوى التعليم، واجه العراق ظاهرة هجرة العقول بأعداد كبيرة، حيث قدر رسميا أن أكثر من بr ألف باحث وعالم وأستاذ جامعي وطبيب متخصص ومهندس تركوا العراق لينضموا إلى أكثر من ه, ب مليون آخرين يعيثون في المنـافي الطواعية،

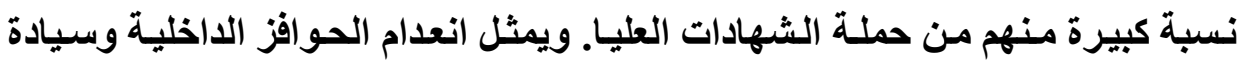

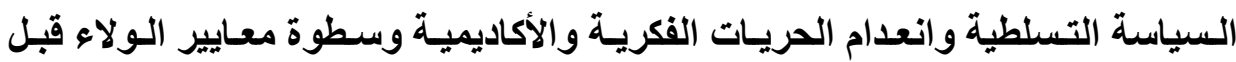
الكفاعة محفزات كبرى لهجرة العقول العراقية أياً كانت الصعوبات التي تواجهها. هذا وقد أشارت تقارير اليونيسيف أن أكثر المناطق تأثراً في العراق هي المنطقة الجنوبيـة والوسـطى، حيث يقطنهـا ه^\% مـن مجمـوع السكان. إذ أن معدل وفيـات

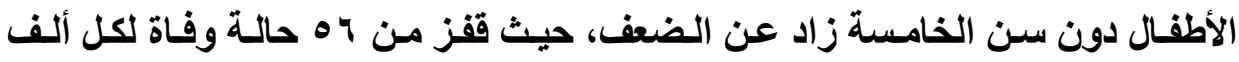

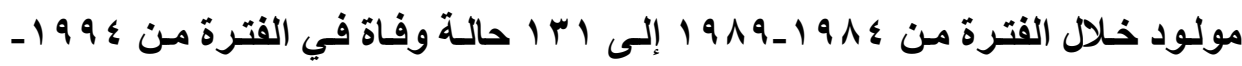


9 9 9 1. وكذلك تزايد معدل وفيات المواليل من V؛ لكل ألف مولود إلى ^ ـ ـ حالة وفاة خلال نفس الفترة السابقة.

وتضاعفت نسبة سوء التغذيـة بين الأطفـال دون سن الخامسة من ب ا \% إلى

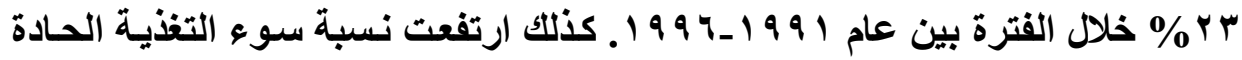

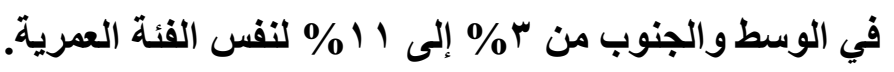

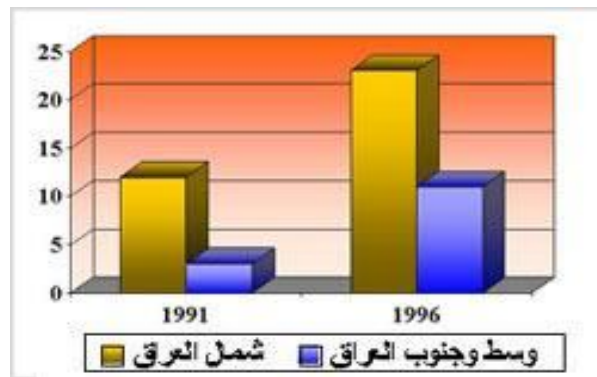

النسبة المئوية لسوء التغذية فى العراق فى أعقاب الحصار الاقتصادى

وعمل برنـامج الأمم المتحدة "النفط مقابل الغذاء" على الحد من تزايد أعداد

الوفيات وحالات سوء التغذية، لكنه لم يعالج الموقف من جذوره. ولم يأت البرنـامج بمـا

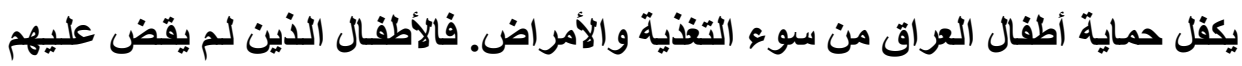
الموت مـازالوا محرومين من الحقوق الأساسية المنصوص عليها في مؤتمر حقوق

الطقل.

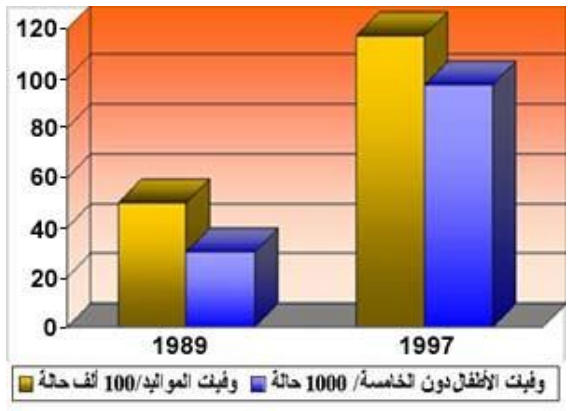

مجلتّ البحوث القانونيتّ والإقتصاديت 
وفيما يتعلق بتأثير العقوبات على شبكات المياه والصرف الصحي والطاقة قبل

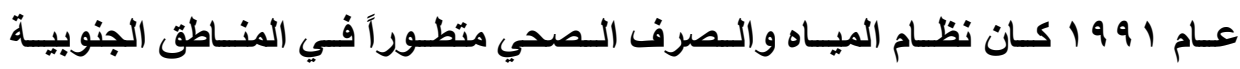

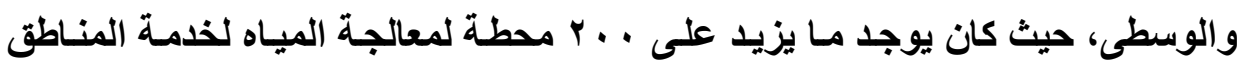

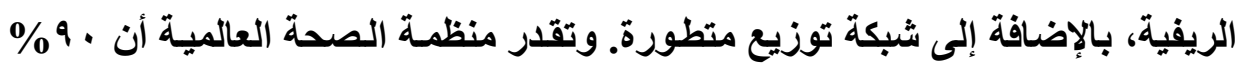

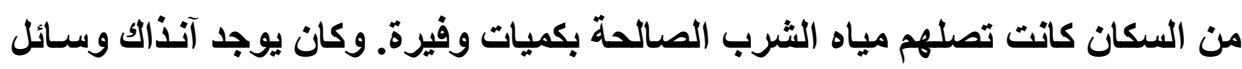

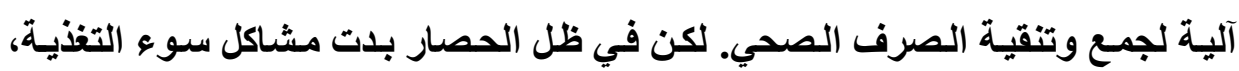

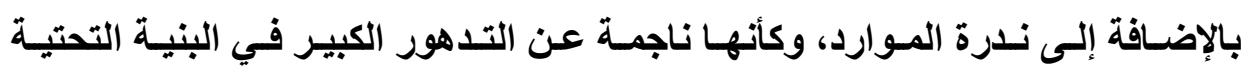
الأساسية، وخاصة في أنظمة تزويد المياه والتخلص من النفايات. كـان الأطفـال دون سـن الخامسة هـم أكثر المتضررين لأنهم كـانوا يتعرضسون

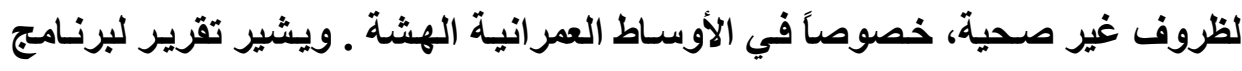

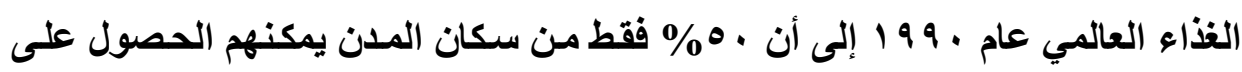

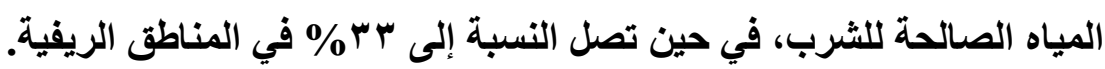
وبالنسبة للطاقة الكهربائية، يثير تقرير برنامج الأمم المتحدة للتنمية أنه بالرغم

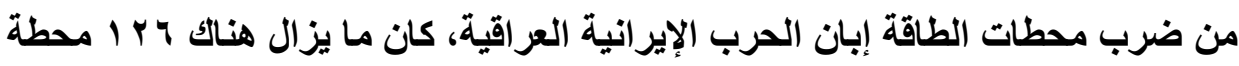

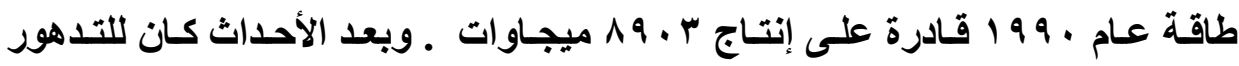

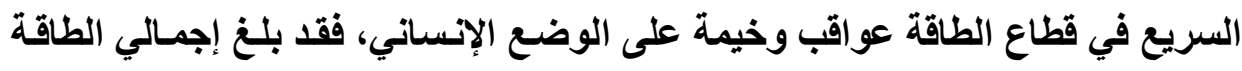

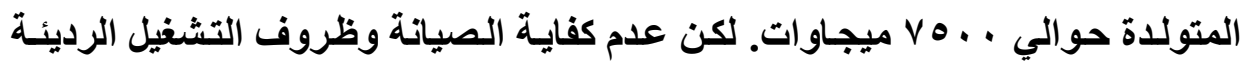

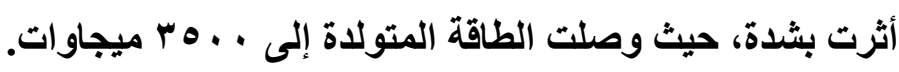
ويشير تحليل لبرنسامج الأمم المتحدة للتنمية إلى أن المعدات القديمة والآثار

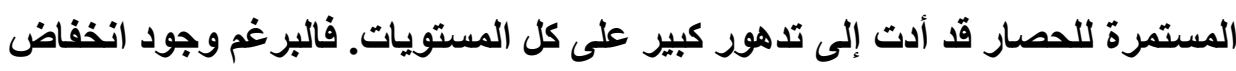

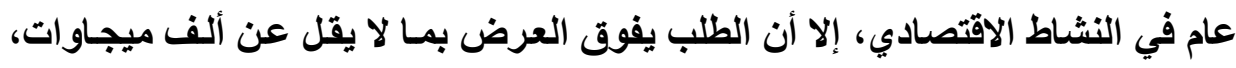

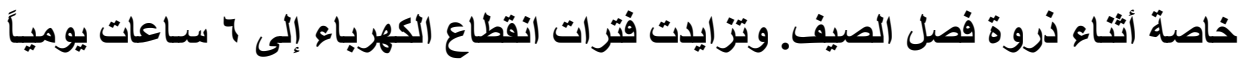

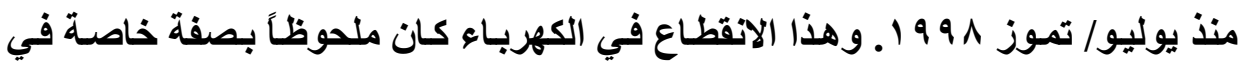


بعض أجزاء المنطقة الثمالية، حيث إن لهذا الاقطاع تأثير ا عكسيا على مخزون المياه

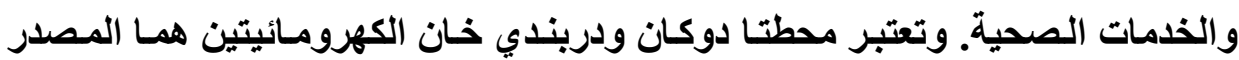

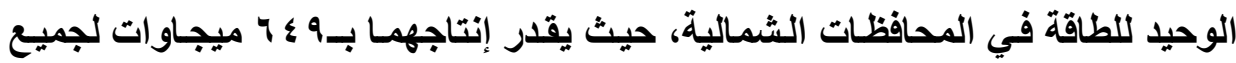

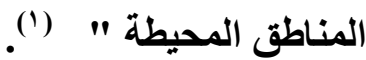

\section{رابهًا :- تأثيز العقوبات الاقتصادية على التنسمية المستداهمة :-}

نتيجة لتركيز النمـوذج الغربى فى التنمية خـلال القرن العشرين على الاهتمـام

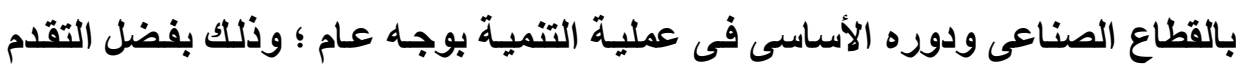

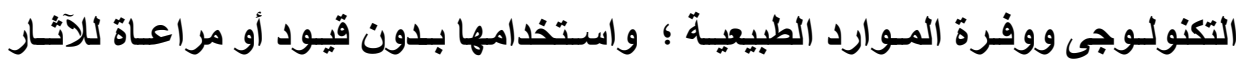

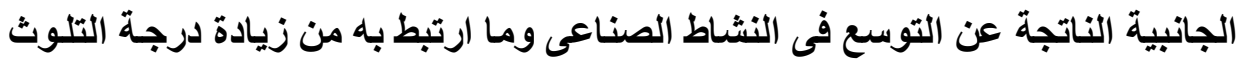

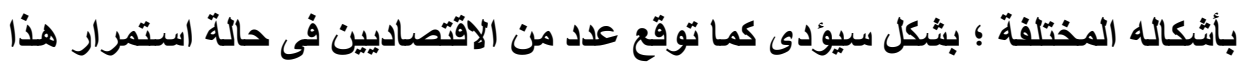

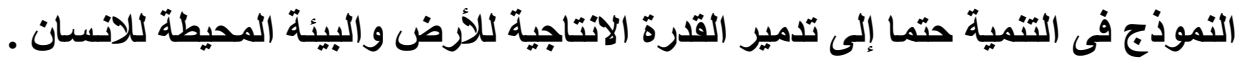
ظهر مـا يسمى بالتنميـة المستدامة كبديل عن المفهوم التقليدى للتنمية وذلك بهدف تعظيم المكاسب الصافية من التميـة الاقتصادية مـع ضـمان المحافظة على على الخدمات

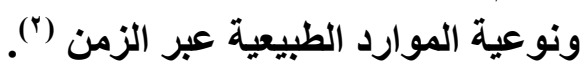

ومن ثم فإن التنمية المستدامة تعتمد على إشباع غايـات متمثلة فى تحقيق

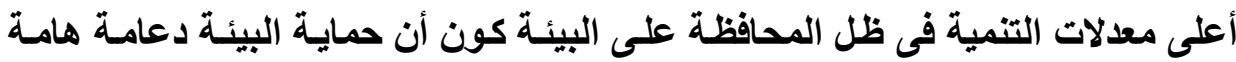

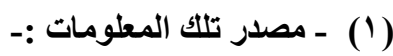

ـ تقرير عن " آثار الحصار على العراق " مركز الداراسات والبحوث بالجزيرة نت :-

http://www.aljazeera.net/portal

ـ تقارير متفرقة صادرة عن اليونيسيف عن أوضاع الأطفال فى العراق .

ـ مقاطع من أعداد متفرقة من مجلة السياسة الدولية

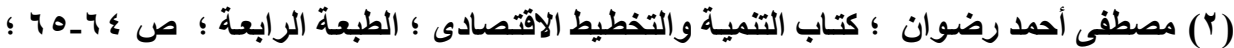

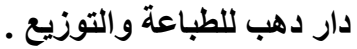


لحمايـة حق الانسان فى الحيـاة الطويلـة ؛ والصحة السليمة ؛ والمأكل النظيف ؛ تلكـ الحقوق التى تتوقف إلى حد كبير على تحقيق مستويات مرتفعة من التنمية .

هذا وتمثل العقوبـات الاقتصادية الدولبـة القسرية انتهاكـاً صـريحاً وواضـحاً

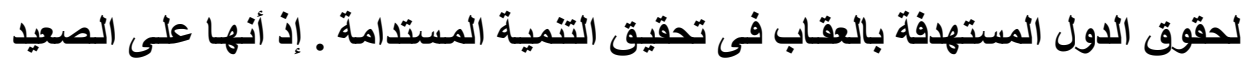

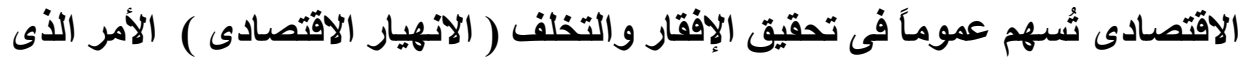
يرتب العجز عن تعزيز

\section{التنسمية الاقتصادية ورفع هستويات المعيشة (1)}

أما فيما يتعلق بآثار العقوبات الاقتصادية وتأثيرها على البيئة فتبرز من خلال

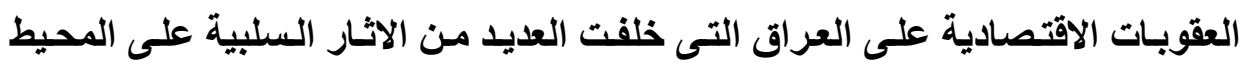

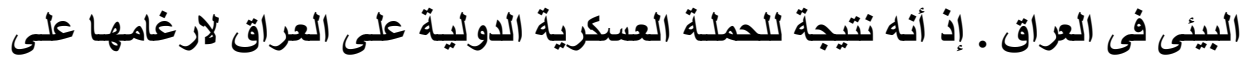

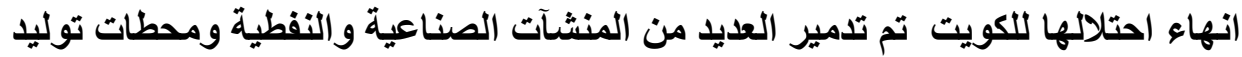
الطاقة الكهربائية ومحطات تصفية المياه ؛ وشبكات الصرف الصحى .... التخ ؛ إضـافة الضئة إلى استخدام الأسلحة الكيماوية وغازات الأعصاب مما أدى إلى وفاة مئسات من الأطفال

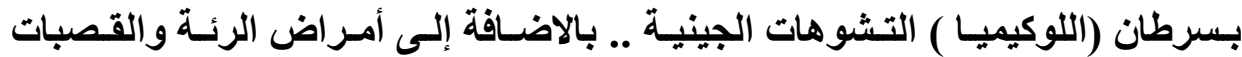

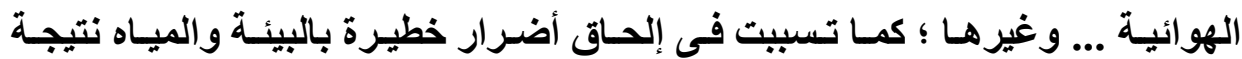

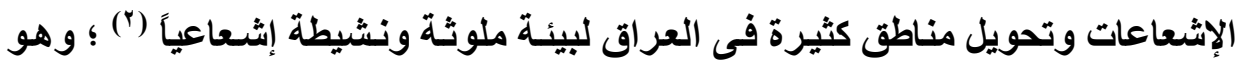

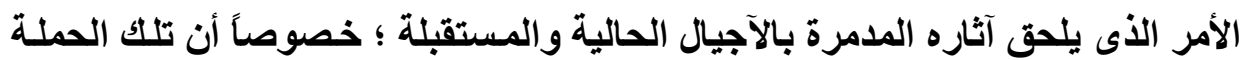

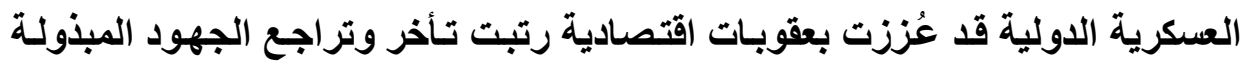

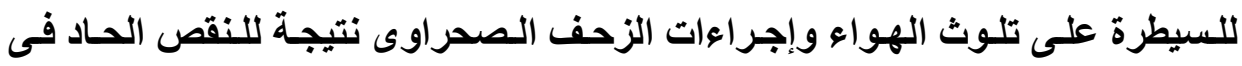

(1) Lektzian David, «Making Sanctions Smarter: Are Humanitarian Costs an Essential Element in the Success of Sanctions? ", Norwegian Red Cross,International Peace Research Institute, Oslo, norway, 2003. P 5 (r) فتيحة ليتيم " عقوبات الأمم المتحدة الاقتصادية و آثارها على حقوق الإنسان فى العراق " رسالة

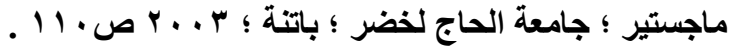


المضخات والمعدات الزراعية ومواردهـا الاحتياطية من البذور والأسمدة ؛ والمبيدات

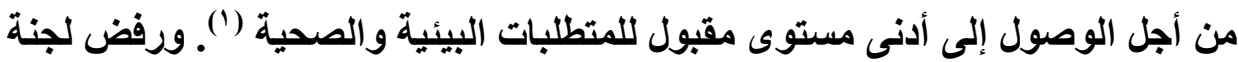

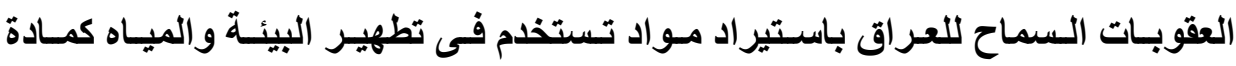
الكلورين بالاضافة إلى معدات أخرى تستخدم فى ترميم و إصلاح البنية التحتية(؟) . إلى جاتب تلوث المياه والتى هى مصدر للحيـاة البيئية السليمة ؛ حيث ازداد التلوث البكتيرى فى ميـاه الشرب ؛ وانخفضت انتاجية مشروعات ميـاه الشرب بعد الحرب والعقوبـات إلى أقل من مباه . . . . مليون متر مكعب سنوياً ؛ وهو مـا يستتبعه انخفاض حصة الفرد من المياه ؛ بالاضافة إلى قيود أخرى ساهمت في مدئ مدم توفر المياه

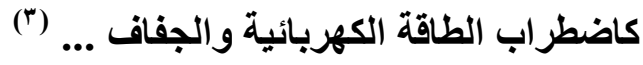

ومما سبق يتضح أن العقوبات الاقتصادية قد انتهكت وأنهكت القدرات العراقية

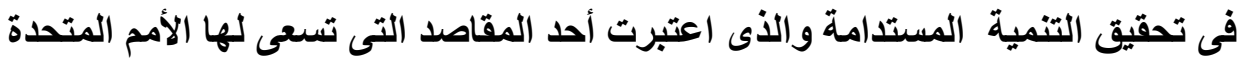

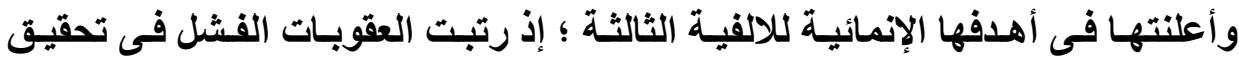

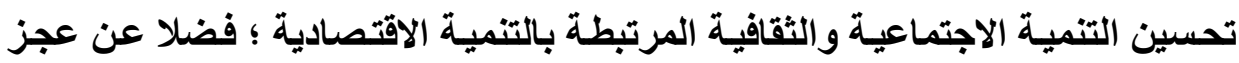

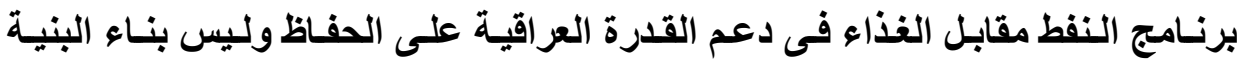

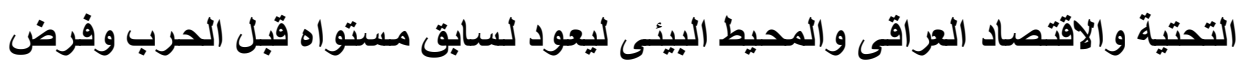

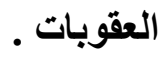
جدير بالأكر أن لجنة التنمية الدولية فى مجلس العموم البريطانى فى تقريرهـا

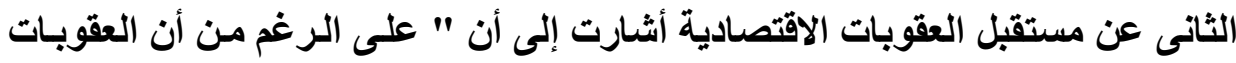

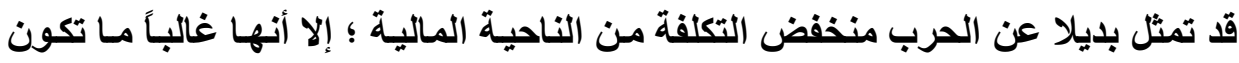

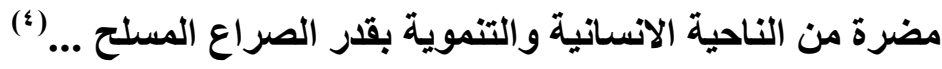




\section{الفصل الثانى}

\section{الآثار الاجتهاعية للعقوبات الاقتصادية على}

\section{الدول المستهدفة بالعقاب}

تتعدد المظاهر الاجتماعية السلبية للعقوبات الاقتصادية الدولية كتدابير قسرية

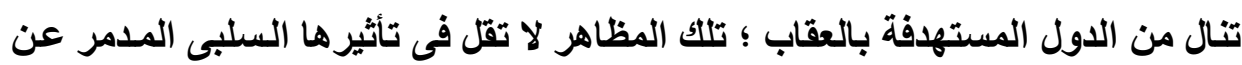

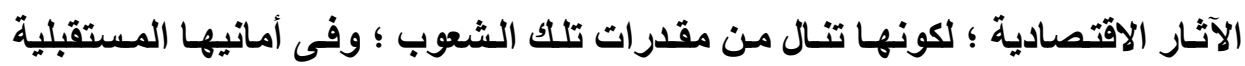

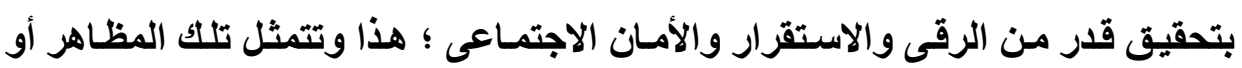
الآثار الاجتماعية السلبية للعقوبات فيما يلى :-

أولا :- تخلخل الطبقات الاجتهماعية فى الدول المستهدفة بالعقاب : :-

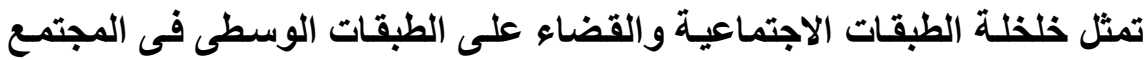

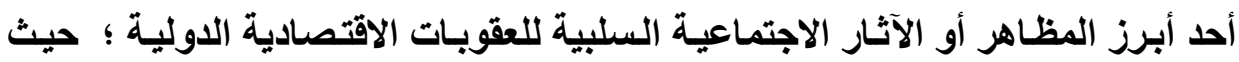

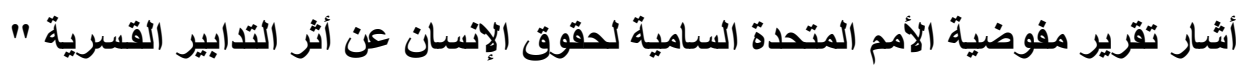

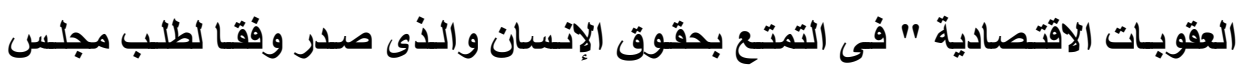

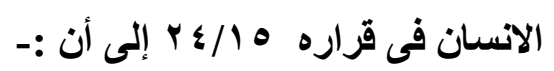

" الجزاءات الاقتصادية تقضى على الطبقة المتوسطة حيث يزداد الفقراء فقراً

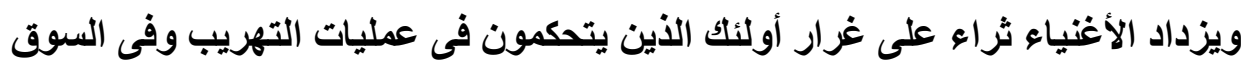

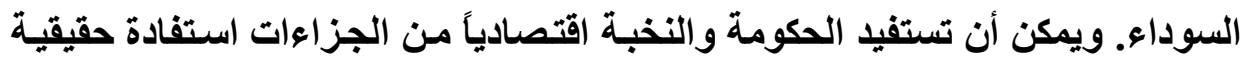
نتيجة لاحتكار هما للتجارة الغير مشروعة ـ وفى ذلك إثـارة على يبدو إلى أن التدابير

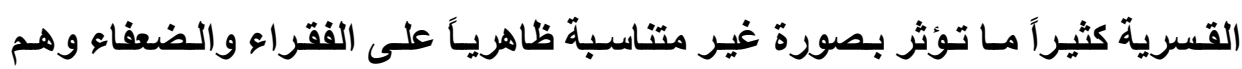
الأثخاص ذاتهم الذين تسعى مبادى عقوق الإنسان لتوفير ضمانات معينة لهم ... هذاء 
وتجنح التدابير القسرية إلى التأثير فى حاجـات السكان الأساسية وبالتالى فى التمتع بأبسط حقوق الإنسان للديهم ـ وعندما تؤثر التبعـات السلبية فى الفقراء والضعفاء والمستضعفين ؛ يمكن أن تؤدى إلى افقارهم للقدرة على الصمود وللحماية الاجتماعية

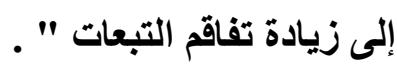

ويؤكد ما سبق أن العقوبات الاقتصادية على ايران كان لها تأثثراً مباشراً على

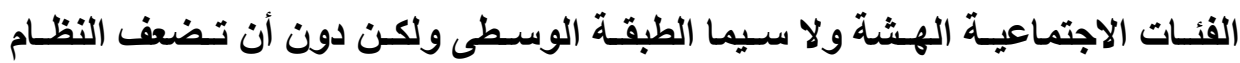
الايرانى الذى شهدت عائداته النفطية زيادة كبيرة منذ عام ه ه. . ب بسبب ارتفاع أسعار

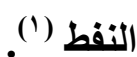

أن الضغوط الاقتصادية التى تفرضها العقوبـات الاقتصادية على ايران وغيرهـا

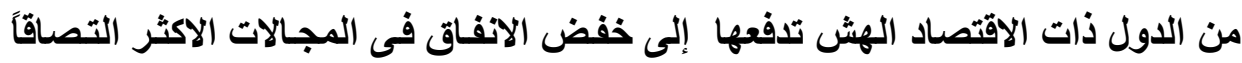
باحتياجات المواطنين وخصوصا الطبقة المتوسطة والمتمثلة فى تخفيضات فى قطاعات مثل التعليم والرعاية الصحية ... ويصاحب ذلك انخفاض قرة هذا الاقتصاد الهش على له توليد فرص عمل بـل يصبح طارداً للعمالة ممـا يؤدى تـريجياً لتفاقم الاوضـاع وتآكل الطبقة الوسطى ودفع الملايين منها الى الفقر والعوز ؛ وانحسار فرص تلك الطبقة الوسطى فى التماسكك والحفـاظ على استقرار ها النسبى بسبب الضغوط الاقتصادية المحيطة بها .

ثانيا :- فقدان التسماسك النفسى والاجتهماعى :رتبت العقوبات الاقتصادية آثار سلبية على البنيان الاجتماعى للدول المستهدفة بالعقوبات ؛ وتجلى ذلك فى المجتمع العراقى ؛ إذ أسهمت النتيجة التى سبق وأن أشرنا

(1) Thiébaut-Azadeh Kian, "L'Iran entre sanctions, destructions et Négociations», Revue Internationale Et Stratégique, Éditions Dalloz/RIS, Paris, 2008. P 80 
إليها فى العنصر السابق ـ خلخلة التركيبة الاجتماعية -إلى تمزق الحياة العائلية نتيجة

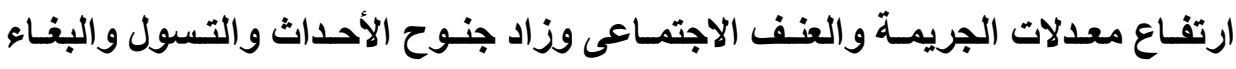
والعزلة الحادة بسبب عدم وجود اتصال مع العالم الخارجى وبروز الاقتصاد الموازى ؛ وسيطرة المنتفعين والمجرمين ؛ والخسارة الناجمة عن تعطل الحركة العلمية والثقافية فى حياة الأسرة ؛ حتى أنه ذكر وفقا لبيانات منظمة الصحة العالمية بأن عدد المصابين

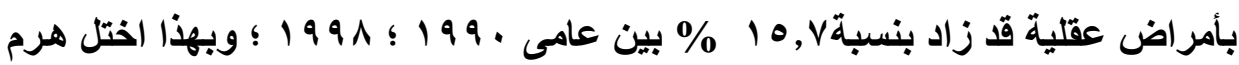

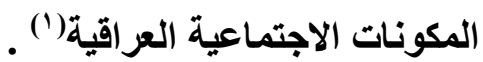

\section{ثالثا :- تدهور وتراجع التعليم ؛ وهجرة الكفاءات العلمية :-}

أسهمت العقوبات الاقتصادية فى تدهور وتآكل القاعدة البنائية التعليمية فى الدول المستهدفة بالعقاب ؛ وهو مـا يبدو جليا فى العراق حيث انها حققت مستوى تعليمياً معتبر ا قبل ، 199 ـ حسب تقارير اليونيسيف - باستثماره مبالغ ضخمة في قطاع التعليم من وسط السبعينات حتى عام ، 99 ا ؛ إذ كان نصيب التعليم يزيد عن ه \% من

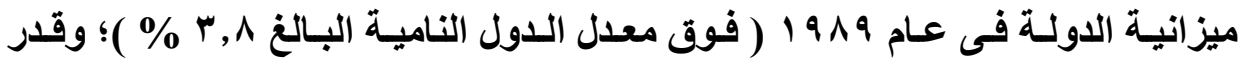
صندوق الأمم المتحدة للطفولة نسبة المتعلمين بنحو ، 9 \% قبل العقوبات ؛ كمـاوصل عدد المسجلين - حسب تقرير لليونسكو - بالمرحلتين المتوسطة والثانوية ه V \% ؛ وبالاضافة إلى ذلك تضمنت السياسة التعليمية فى العراق توفير منح دراسية ودعم طبى للطلبة المعوزين إلا أن هذا الوضع تغير بعد ـ99 9 ؛ ؛ أى بعد تعرض العراق للعقوبـات

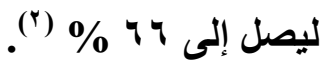

(1) Tehindrazanarivelo Djacoba Liva, Les Sanctions des Nations Unies et leurs effets secondaires: assistance aux victimes et voies juridiques de prévention, Presses Universitaires de France, Paris, lére édition, 2005.pp 143-144

$$
\text { فتيحة ليتيم ؛ مرجع سبق ذكره ص } 19
$$


وفى أعقاب الحصار الاقتصادى على العراق اتسعت الفجوة فيمـا يتعلق بـالتطور العلمى والتكنولوجى بين العراق والعالم الخـارجى ؛ فلم يعد بإمكان الجامعات العراقية

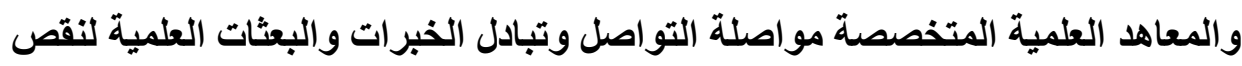
الموارد المالية المتاحة ('). كما أثرت العقوبات على بنـاء المبانى المدرسية والجامعية

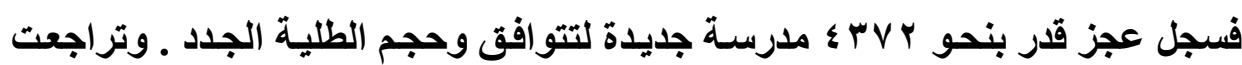

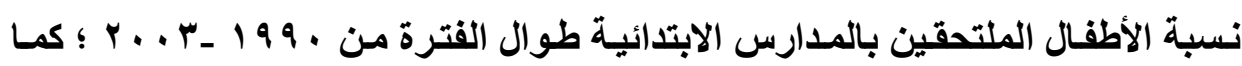

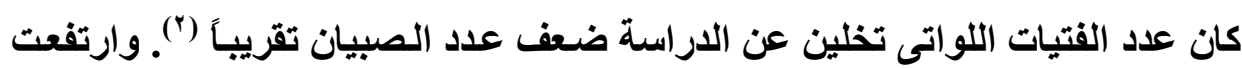

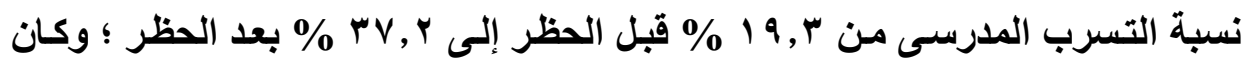

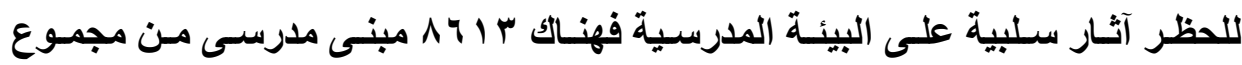

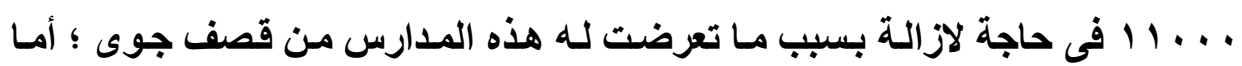

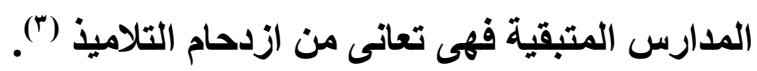
كما أشارت تقارير اليونيسيف فى عام 99 19 إلى نسبة الأمية بين البالغين قد

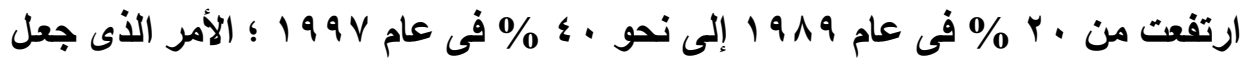
من النظام التعليمى بـالعراق فى ظل العقوبـات الاقتصادية يمثل حصارً فكريـاً مفروضـاً

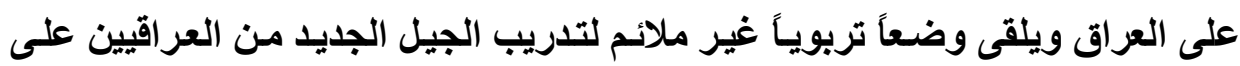

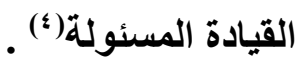

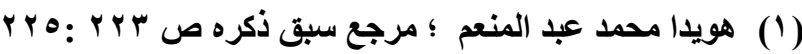

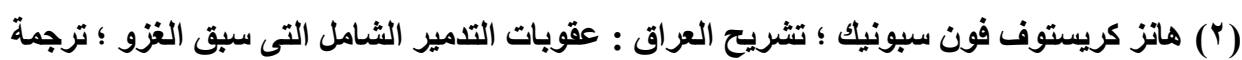

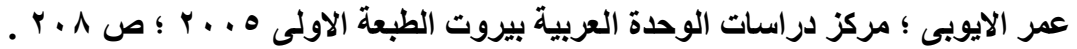

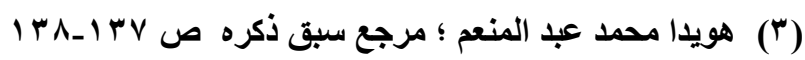

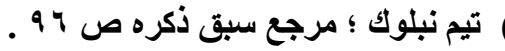


والى جاتب هذا ؛ شهدت العراق ظاهرة هجرة العقول بمستويات عالية حيث يقدر

رسمياً أن أكثر من ب r ألف باحث وعـالم واستاذ جـامعى وطبيب ومهندس غـادروا

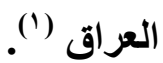

جدير بالذكر أن هنـاك بعض الآثـار الاجتماعيـة التى لعقت بالـدول المستهدفة

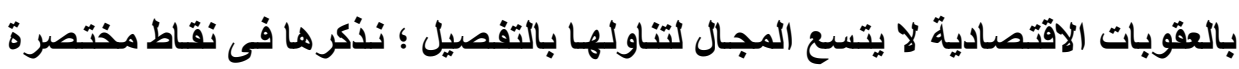

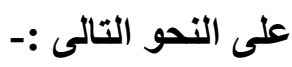

حيث تسببت العقوبـات الاقتصادية لترتيب بعض الاثار الاجتماعية السلبية فى

$$
\text { دولة كالسودان وهى :- }
$$

- - تنـامى التطرف والأرهـاب وسـ الشباب والنظر للسلاح كوسيلة فاعلـة لتحقيق المطالب بما يسهم فى تهديد الامن الوطنى والاقليمى . - تزايد فرص الاتجار بالبشر وانواع الجريمة المنظمة عموماً . - - تزايد انتشار المخدرات وسط الثباب بسبب الهزيمة النفسية الناجمة عن البطالـة

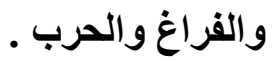

- - تهذيد الأمن العالمى وأمن المستقبل خاصة فيمـا يتعلق باستخدام الموارد وحمايـة

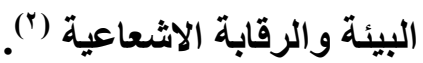

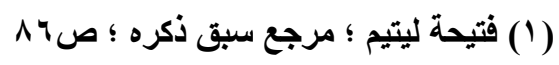

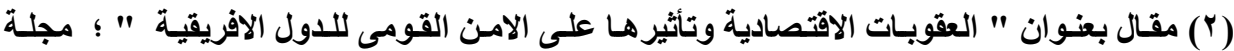

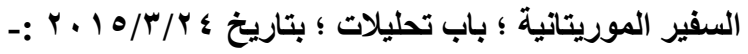

http://essevir.mr/index.php/287013-10-03-14-11-07/12521-2015-03-24-1803-27.html 


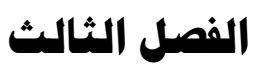

\section{اثار العقوبات الاقتصادية الدولية على دول الجوار}

يصاحب فرض العقوبـات الاقتصادية على الدول المستهدفة بالعقـاب ؛ عدد من الآثـار بعضها إيجـابى ؛ والبعض الآخر سلبى على دول الجوار لتسك الدول ســــاول عرض بعض تلك الآثار وسنركز فى ذلك على دولتى الأردن ومصر كنموذج للدول الجوار للاول المستهدفة بالعقوبات الاقتصادية وذلتك على النحو التالى :-

أولاً :- الآثار الإيجابية لفرض العقوبات الاقتصادية على دول الجوار :-

أـ فيمـا يتعلق بالمملكة الاردنيـة الهاثـية فقد صساحب فرض العقوبـات الاقتصادية على العراق ؛ عدد من الاثار الايجابية على المسار الاقتصادى الاردنى ؛ تمثل فى الإنى

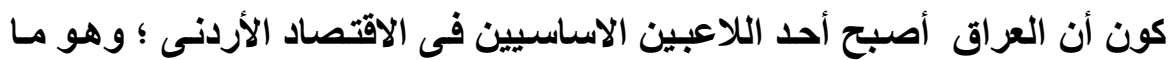

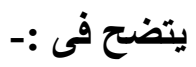

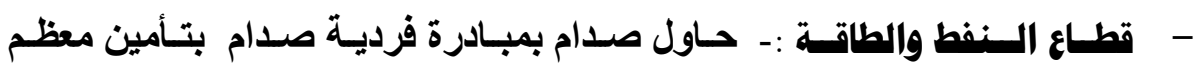
احتياجـات الأردن من الطاقة بأسعار دون أسعار السوق قبيل فرض العقوبـات على العراق بل وازداد الأمر خلال فرض العقوبـات باعتبـار الاردن أحد المنافذ الرئيسية للعراق كما سيتضح لاحقاً ؛ حيث باع العراق النفط إلى الأردن بأسعار دون مستوى أسعار السوق بعد إرساء برنـامج النفط مقابل الغذاء التابع للأمم

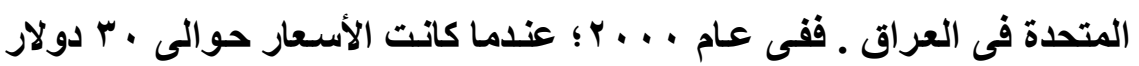

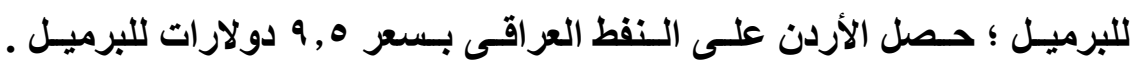
وعلاوة على ذلك سمح العراق للاردن ؛ وهو بلد لا يملك موارد داخلية للطاقة ؛ بأن يؤدى ثمن النفط المدعوم على شكل سلع استهلاكية . 
التجارة :- ازدهرت التجارة بين العراق والمملكة الأردنيـة الهاشمية فى أواخر

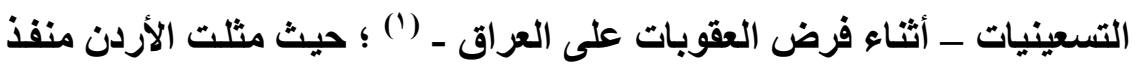
تجارى للعراق لتوفير احتياجاته من العملات الأجنبية ــوتمكن العراق من خلافل برنامج الأمم المتحدة من تمرير عقود مميزة للاردن ؛ ومنحت بعض الشركات الشاته

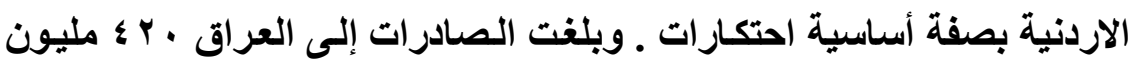

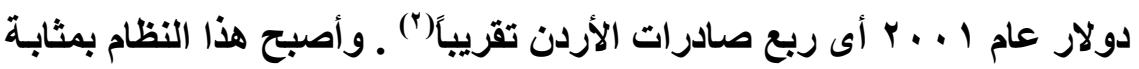

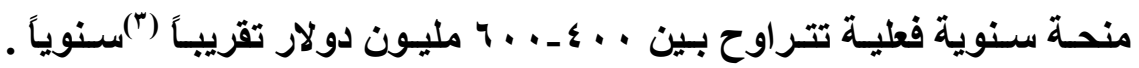

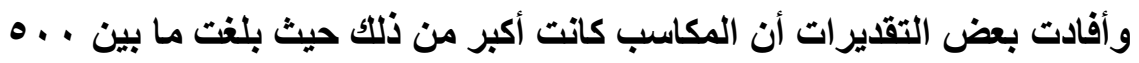
مليون دولار ومليار دولار سنوياً (؛)" (•) - - سـوق العقـارات :- ازدهر سـوق العقارات بـالأردن ذلكك أن العراقيين كـانوا

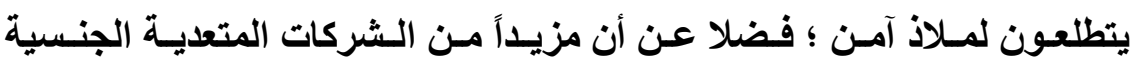

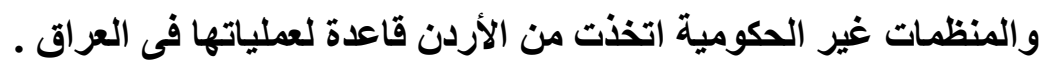

(1) وفى ذلك غضت إدارة كلينتون الطرف واعتبرت ذلك حلا وسطاً لا يمكن تجنبه من أجل الإبقاء على نظام العقوبات الدولية الواسع النطاق .

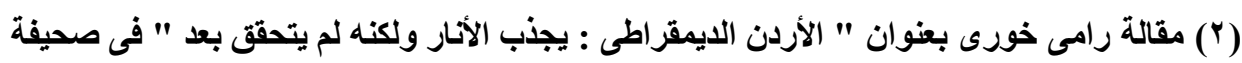

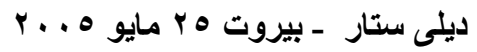

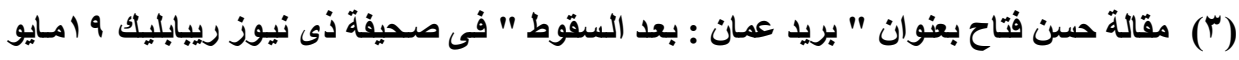
$r . r$ (؛) مقالة ديفيد شنكر بعنوان " الرقص مع صدام :- التانجو الاستراتيجى للعلاقات الاردنية العراقية

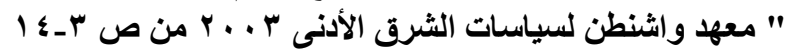

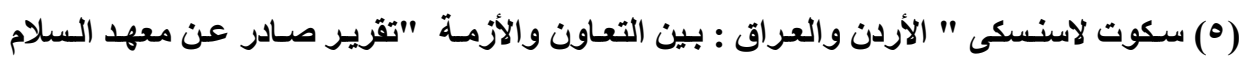

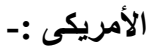

1200 17th Street NW $•$ Washington, DC $20036 \cdot 202.457 .1700 \bullet$ fax 202.429.6063 • p5 
- القطــاع المسصرفى :- فـأن القواعد المرنـة المتبعـة فـى المملكـة فيمـا يتعلق

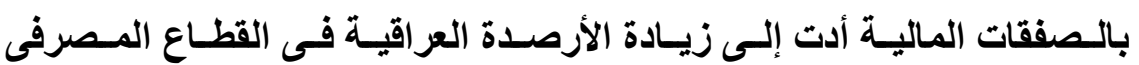

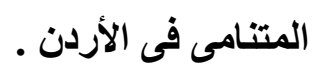

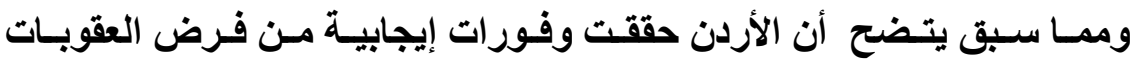
الاقتصادية على العراق حيث حققت نمو اقتصادى قوى نتيجة لكونهـا أصبحت تلعب دور بوابة المرور للعراق - وهو دور بدأته إبان الحرب الأيرانية العراقية

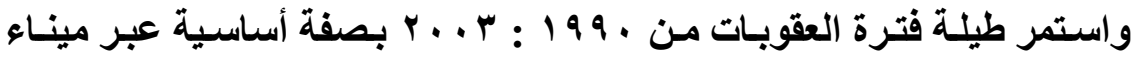
العقبة الأردنى على البحر الأحمر والطريق البرى - وهو الأمر الذى عوض تراجع السياحة بها . بـ فيما يتعلق بجمهورية مصر العربية فقد صاحب فرض العقوبات الاقتصادية على

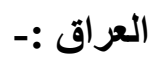

- ازديـاد الطلب على النفط المصري ليسجل ارتفاعًا ملحوظكا مـع ثبـات تقريبًا الاستهلاك المحلي مـن هذه المنتجـات. وهو مـا يتضح من الزيـادة في ميزان

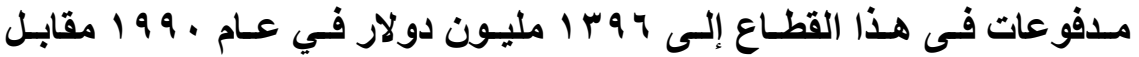
9 1 1 ـ مليون في عام 9 19 1 ، وكان هذا محصلة لزيادة قيمة صادرات البترول

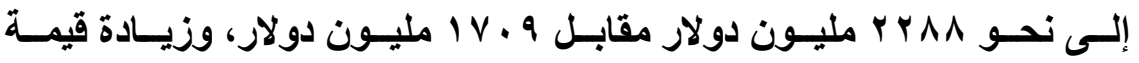

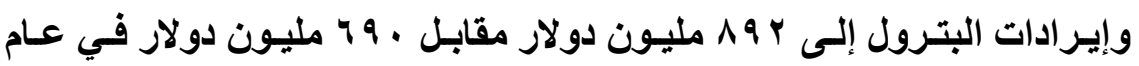

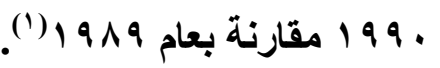
- الإعلان عن تثكيل ثلاث صناديق لمساعدة البلدان المتضررة من أزمـة الخليج وفرض العقوبات الاقتصادية، وخاصة مصر، وهي: 
د/ مصطفى أحمد حامد رضوان

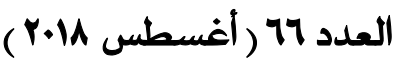

1 ـ صندوق يضم الولايـات المتحدة الأمريكيـة وأوروبـا الغربيـة والـدول العربيـة

الخليجية.

r ـ الصندوق الياباني وهو عبارة عن اثنين مليار دولار قروضًا طويلة الأجل تسدد

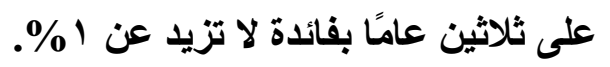

r- ـ صندوق خاص بمصر، وهذا عوض عن الصندوق الأي كان من المزمـع إنشاؤه بالتعاون مع صندوق النقد الدولي، لمساعدة محدودي الدخل الذين سيتأثرون

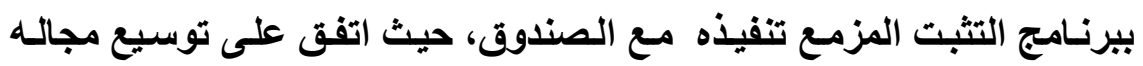

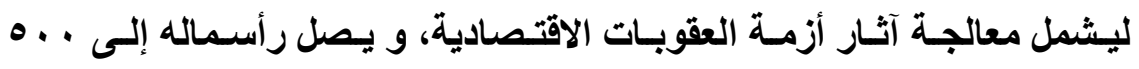
مليون دولار كمنح لا ترد، ومن أمريكا واليابان والكويت و ألمانيا وفرنسا.

\section{ثانيًاً :- الاثار السلبية للعقوبات الاتقصادية على دول الجوار :-}

1- الضغط على الموارد الاقتصادية بسبب زيادة عدد اللاجئين ؛ حيث أنه فى الحالة

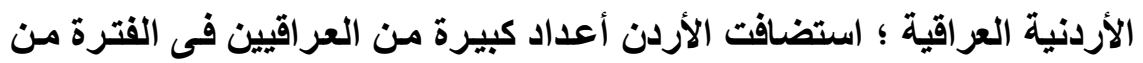

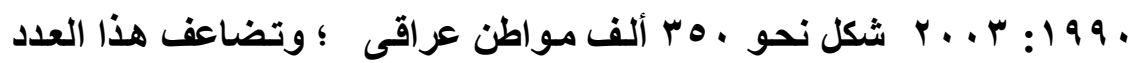
بعـ الغزو الأمريكى للعـراق ووصـل لمليـون عراقـى بـسبب عـدم الاسـتقرار

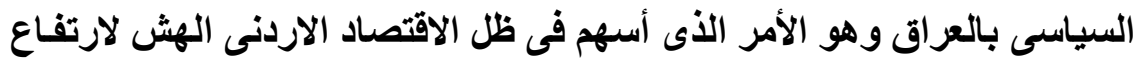

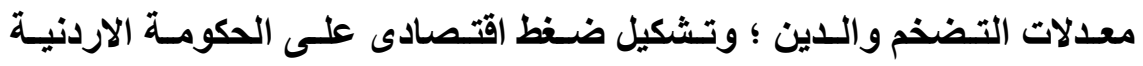

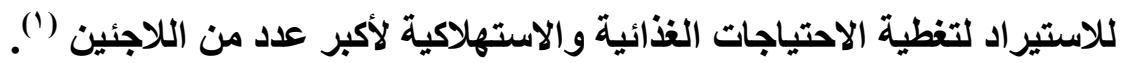
r- رتبت العقوبات الاقتصادية على كلا من العراق وليبيا أزمـة كبيرة نحو مصر

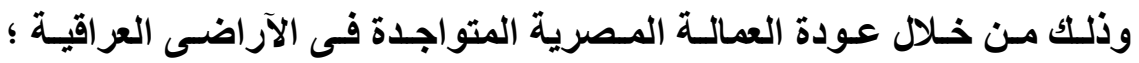

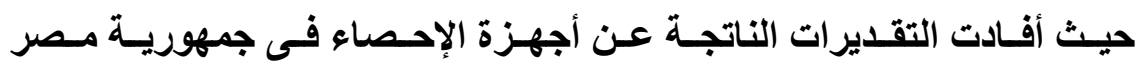
(1) تقرير آفاق الاقتصاد الاقليمى الصادر عن صندوق النقل الدولى ـ منطقة الثرق الأوسط وشـمال

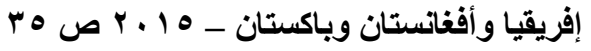


العربية ؛ ووزارة القوى العاملة والهجرة فى مصر أن هنالك نحو نصف مليون

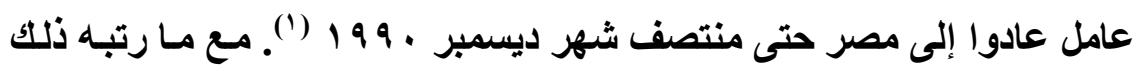
من: :-

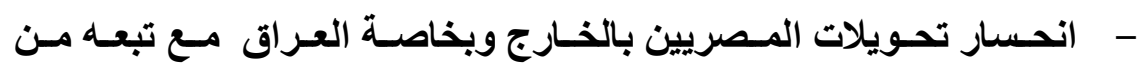

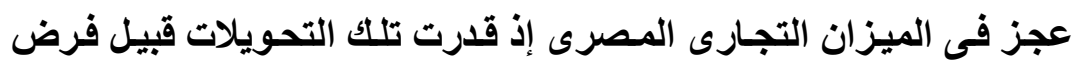

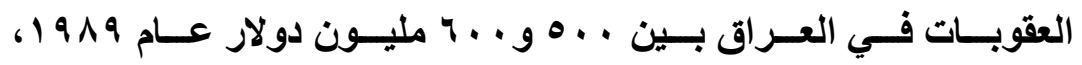

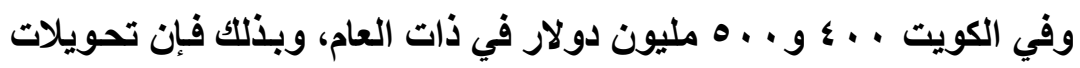

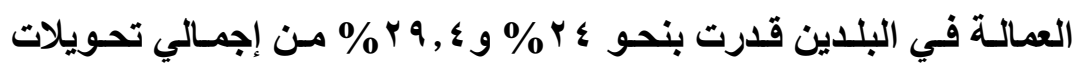

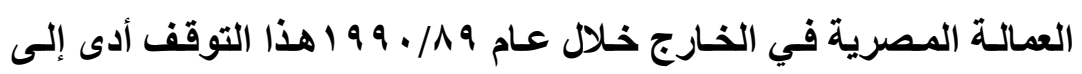

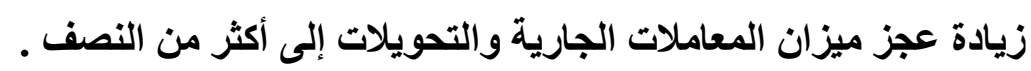
- فضلا عن ارتفاع مؤشر البطالة فى جمهوريـة مصر العربية ليصل نحو

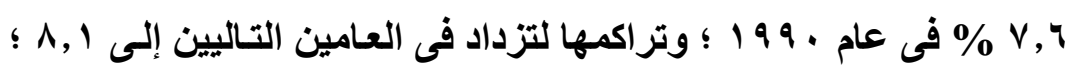

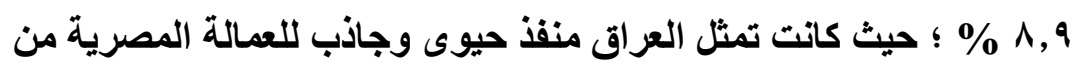

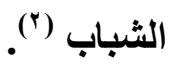

- وما سبق يتضح منه أن العقوبات الاقتصادية الدولية صاحبها آثار ايجابية

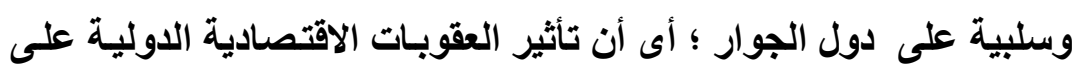

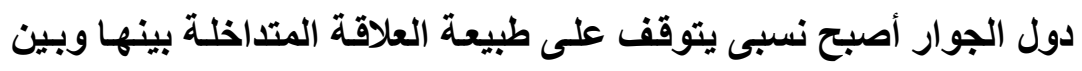
الدول محل فرض العقوبات .

(1) الغزو العراقي، العقوبات الاقتصادية قصمت ظهر الاقتصاديات العربية، مشعل الحميدي، شبكة

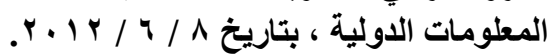

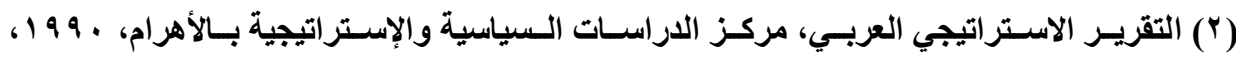




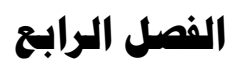 \\ هل تقع هصر تحت طائلة العقوبات الدولية فى أعقاب حادثة \\ سقوط الطائرة الروسيسة فى اسيناء ؟}

فـى أعقـاب حادثـة سـقوط الطـائرة الروسـية المُقلعـة مـن مطسار شـرم الشيخ

بجمهورية مصر العربية إلى مطار سان بطرسبرج فى روسيا ومقتل عدد ؟ Y Y سـائح ؛

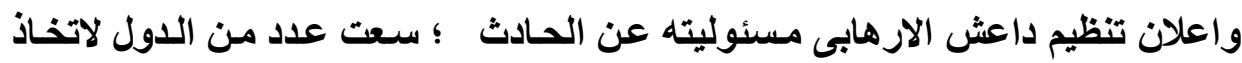

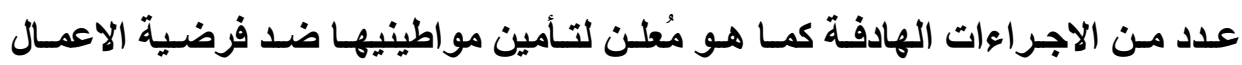

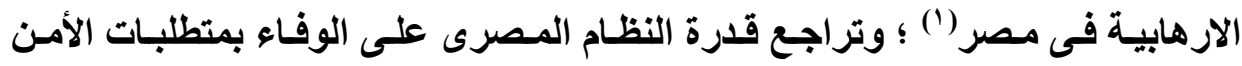

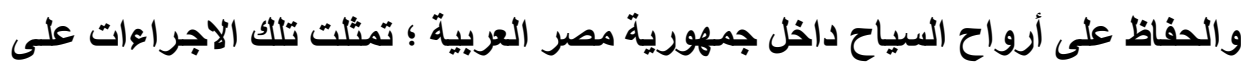

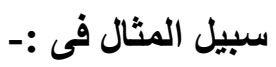

- - شركتان تابعتان لمجموعة لوفتهانزا تقرران تعليق رحلاتهما إلى شرم الشيخ .

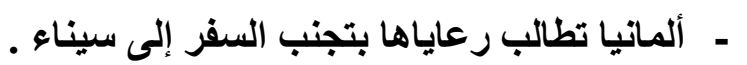

- بريطانيا تقرر تعليق رحلاتها إلى شرم الشيخ بـالتزامن مـع بـدء زيـارة رسـمية

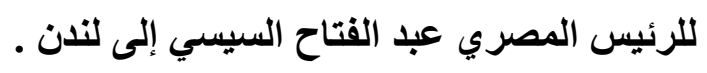$$
\text { - السائحون الروس يغادرون المنتجعات المصرية إلى روسيا ـ }
$$

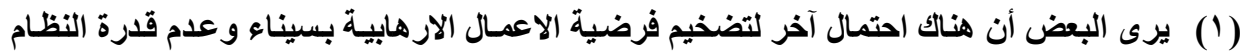

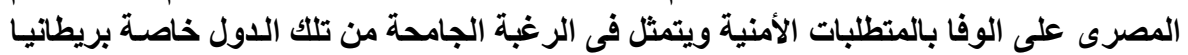

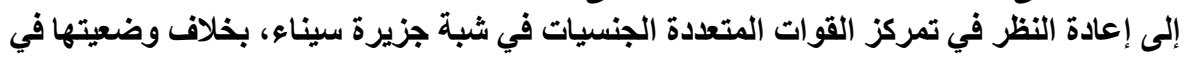

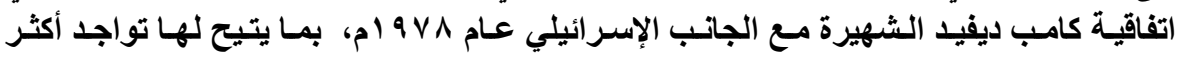

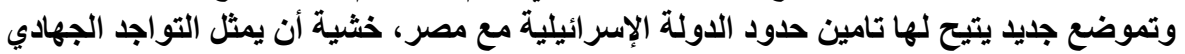

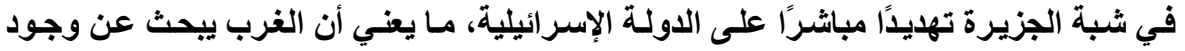

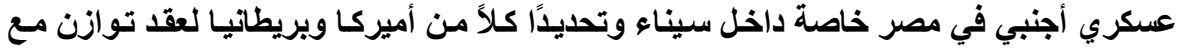

$$
\text { نظيره الروسي في الداخل فير السوري }
$$


- الرئيس بوتين يُصدر مرسومًا رئاسيّا يتضمن فرض حظر مؤقت على شركات الطيران الروسية فيما يتعلق بنقل المواطنين من أراضي روسيا إلى أراضي مصر،

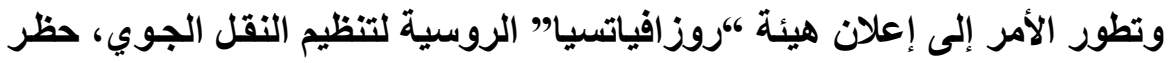
رحلات شركة مصر للطيران إلى روسيا. القرار الأخير بحظر رحلات شركة مصر إعرئ للطيران إلى روسيا، ليس مرتبطا بثركة مصر للطيران كثركة بقدر مـا لـه علاقة

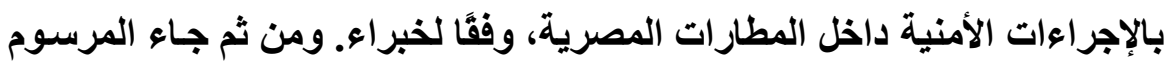

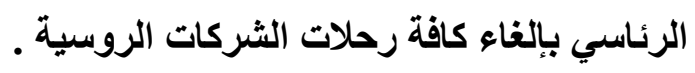

والسؤال الأى يطرح نفسه هو :- هل تعد تلك الاجراعات بمثابـة عقوبـات دولية تجاه مصر على أصر الرغبة الدولية التى تحمل فى بواطنها أغراض سياسية دولية

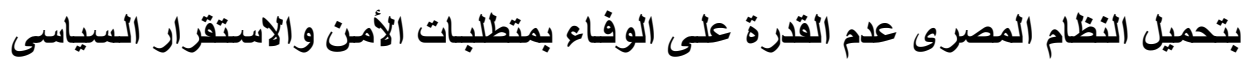
لارغامها على دفع فواتير تلك الاغراض السياسية ؟ فى إطـار مـا ذكرنـا أن العقوبـات الاقتصادية الدوليـة عبـارة عن " " إجراء اقتصادى يهاف إلى التأثير على إرادة دولـة فى ممارسـة حقوقها لحملها على احترام

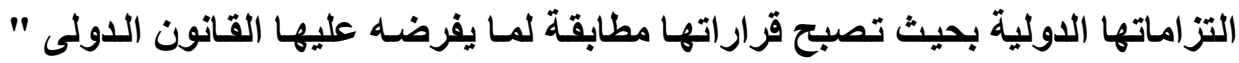
ويحمل هذا الاجراء فى باطنـة سمة التدبير القسرى العقابى بفرض عقوبـات تجاريـة تثمثل فى قيود على تدفق ( البضائع ـ الخدمات ـ الأموال ـ الرقابة على الأسواق ) . ومن ثم فما تواجه مصر من إجراءات بمنع أو تحجيم السياحة الأجنبية الورادة

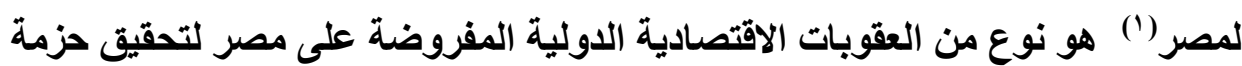

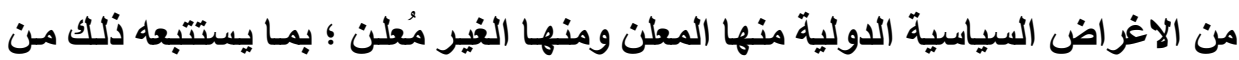
العواقب الوخيمة على الاقتصاد المصرى ـ 
وإذا ما حاولنا إبراز التبعات السلبية لتلك العقوبات على مصر :-

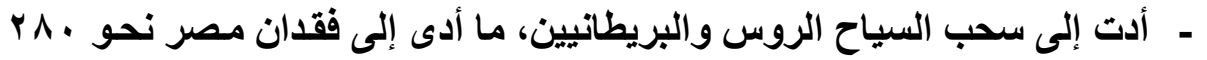

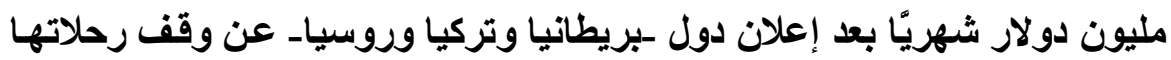

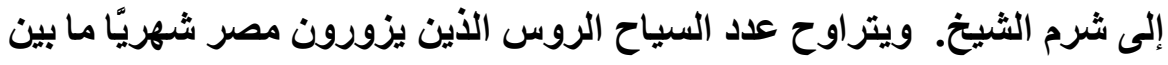

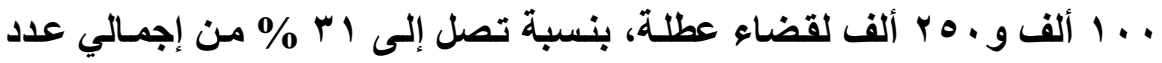

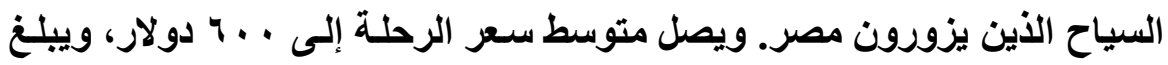

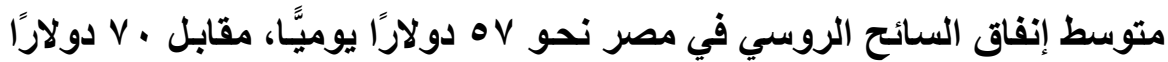
للسائح البريطاني. جدير بالذكر أن روسيا تحتل المركز الأول في قائمسة الدول المصدرة للسياحة

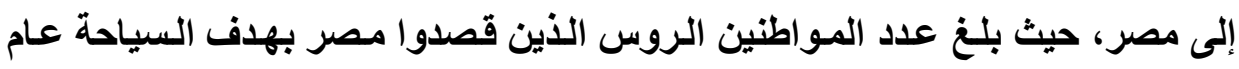

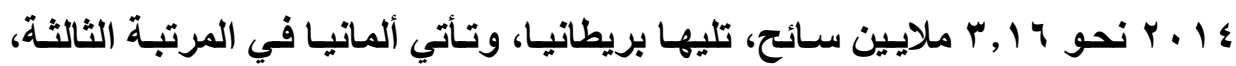
وشكل العياح الروس خلال هذا العام ربع إيرادات مصر من العملة الأجنبية خلالل العام

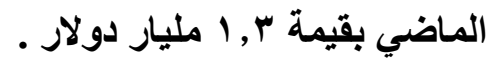

ـ ذهبت مؤسسة موديز العالمية للتصنيف الانتماني إلى إن حادث سقوط الطائرة

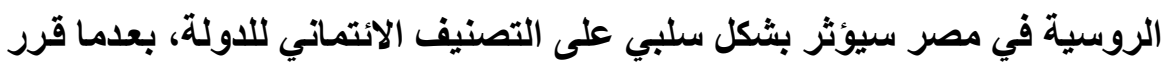

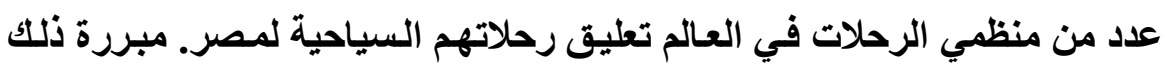

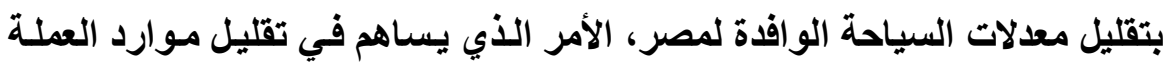
الأجنبية والتأثير على موقف مصر الانتماني .

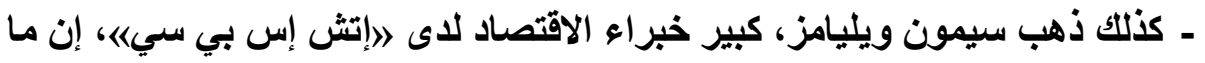

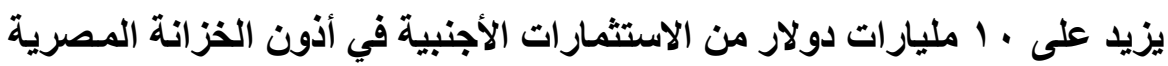

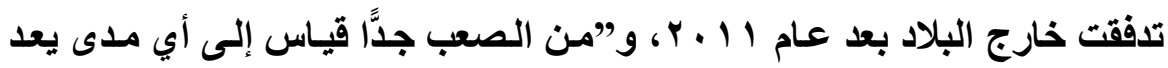
الجنيه في حاجة إلى التراجع . 
ـ ارتفعت خسائر رأس المـال السوقي لأسـهم السشركات المـصرية المدرجـة فـي

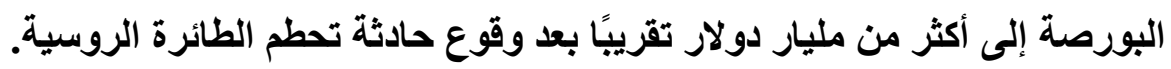

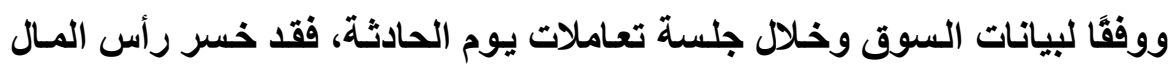

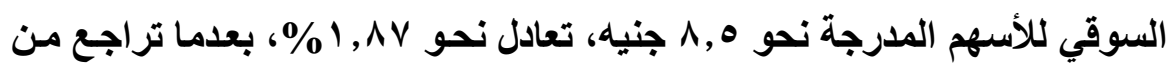

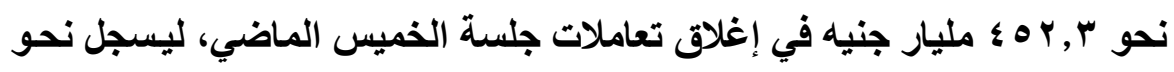

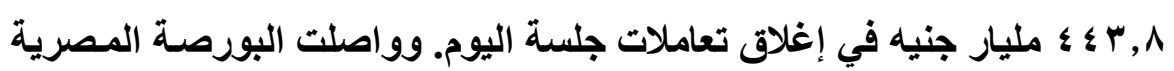

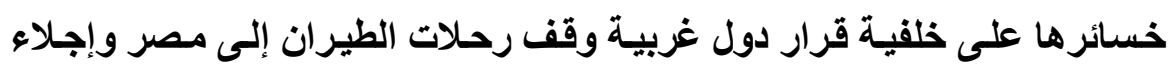

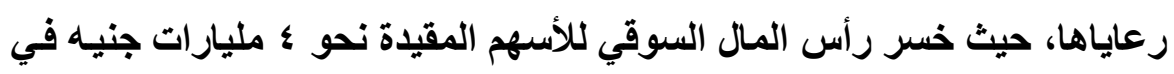
ه 10

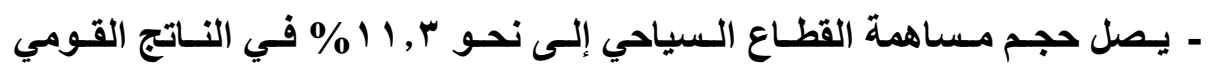

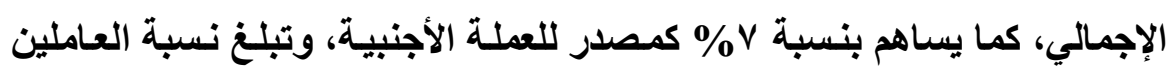

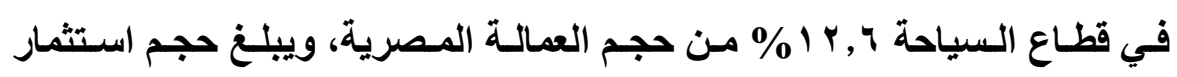

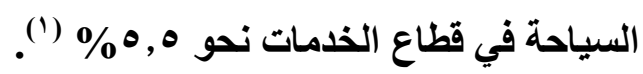

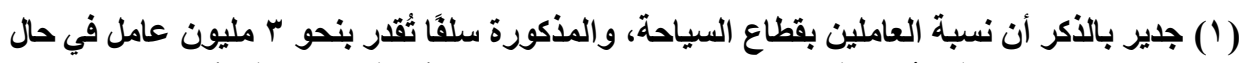

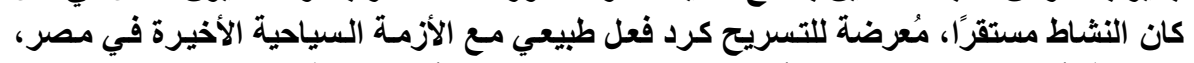

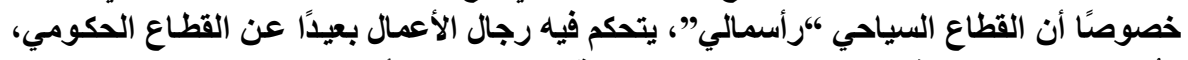

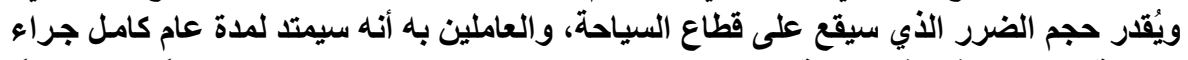

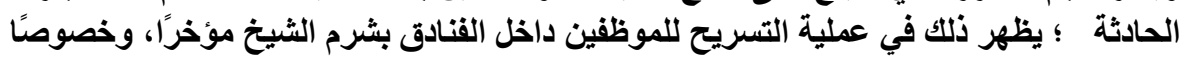

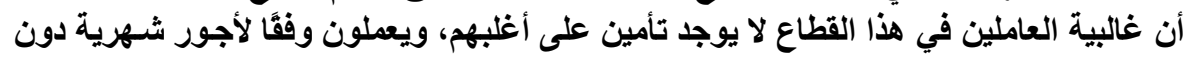

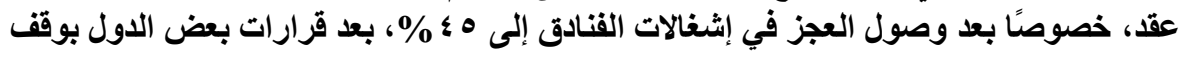

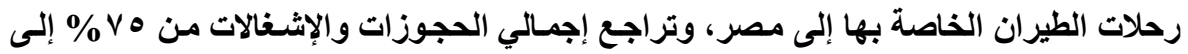
\%r.

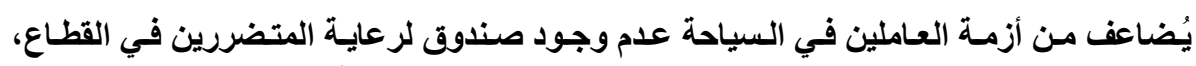

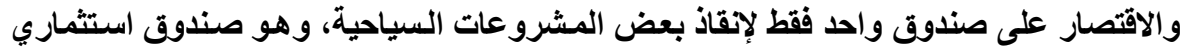

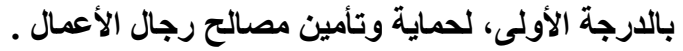


- ووفقَـا لمعاهـدة مونتريسال ، 99 1، التـي وقعـت عليهـا أغلب شـركات الطيـران

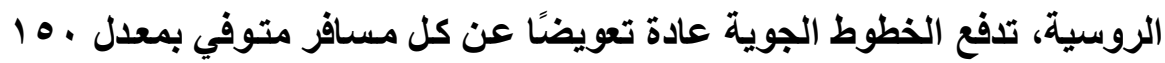
ألف دولار حال كان هذا الخطأ بعيدًا عن الشركة، وتصل هذه القيمة إلى ب ملايين دولار لكل ضحية حال ثبوت التقصير في اتباع معايير الأمن والسلامة المُتبعة من

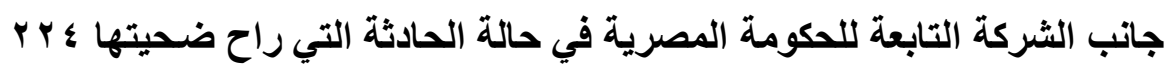
مسافرًا أغلبهم روس .

ترتيباً على ماسبق يتضح لنا أن الاجراءات التى اتخذت تجـاه مصر فى أعقاب حادثة سقوط الطائرة الروسية قد حققت ذات الآثار التبعية ( الاقتصادية والاجتماعية ) للعقوبات الاقتصادية الدولية التى ذكرنها فيما سبث المتمثلة فى :-

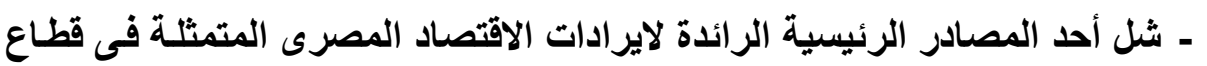

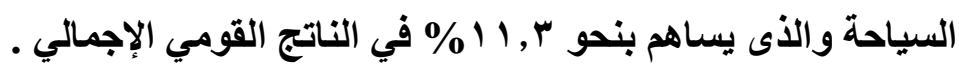
- التأثير السلبى على مقومات الاقتصاد الكلى المتمثئة فى ( إنخفاض الناتج المحلى الإجل

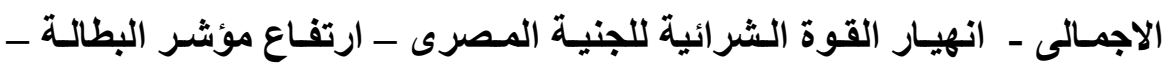
إضـعاف القدرة على تصدير الخدمات السياحية ـ تنـاقص الاحتياطيـات النقديـة الاجنبية واهتزاز سعر الصرف ـ عجز الموازنة العامة ...الخ ) .

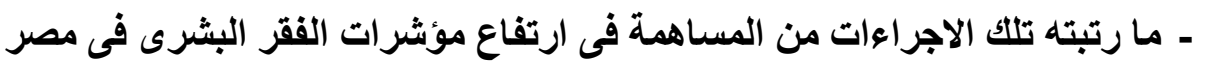

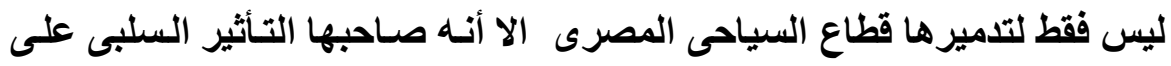
كل الصناعات المغذية التي يعتمد عليها قطاع السياحة، مثل الصناعات الغذائية

$$
\text { والحرف اليدوية والمفروشات والنقل وغيره . }
$$

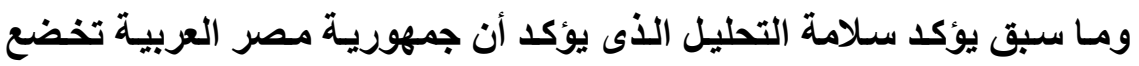

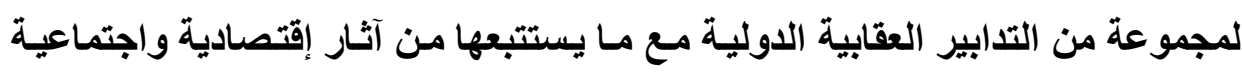

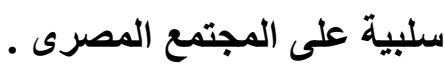




\section{الخاتهة}

إن ما تخلفه العقوبات الاقتصادية كأداة سياسية دولية لارغام الدول المُعاقبة للعدول عن السلوك المخالف للنسق الدولى من آثار إقتصادية واجتماعية سلبية مدمرة على تلك الدول المُعاقبة ؛ وكذا ما يصاحبها من آثار سواء أكاتت إيجابية أو سلبية لدول الجوار ؛ يجعلنا نطرح تساؤل عن مدى جدوى تلك العقوبات المدمرة في تحقيق أهدافها

وفى هذا سنجد أن هناك العديد من الدراسـات التى أجريت فى هذا السياق ؛ أبرزها الدراسة التى أنجزها كليف مورغان، ونافين بابات، وفالانتين كروستيف، وهي

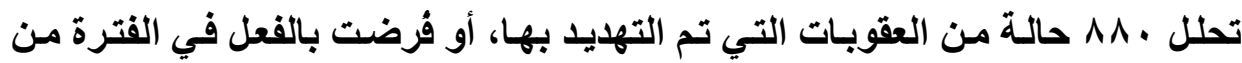

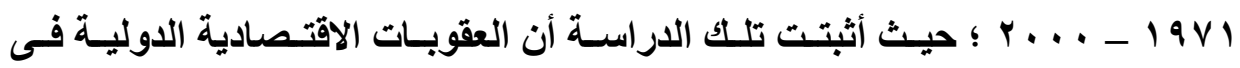

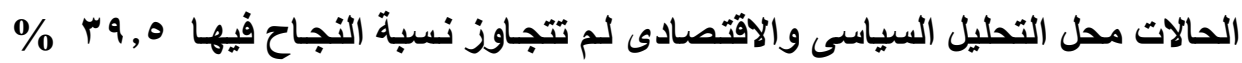
لاى فرض العقوبات من جاتب واحد، و ^, ؛ ه \% مين تكون جماعية .

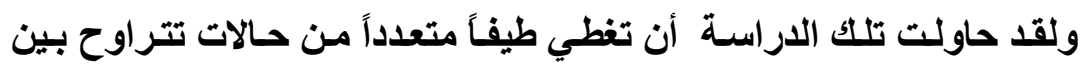
عقوبـات محدودة وعقوبـات كاملة. و الفرق بين الأولى والثانية هو أن الأولى تحداد

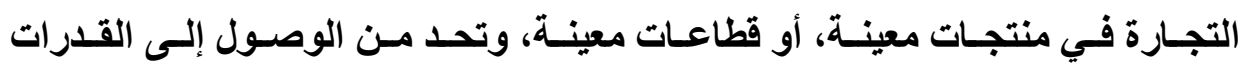

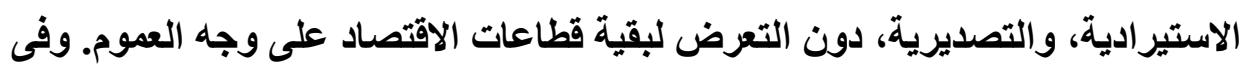

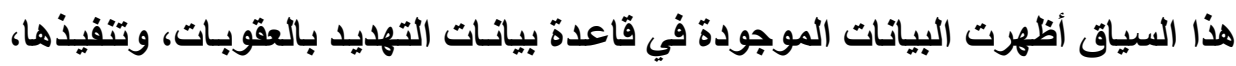
أن فرصة نجاح العقوبات الثاملة أقل من العقوبات المحدودة .

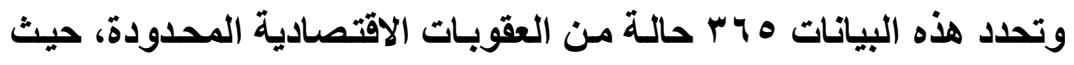

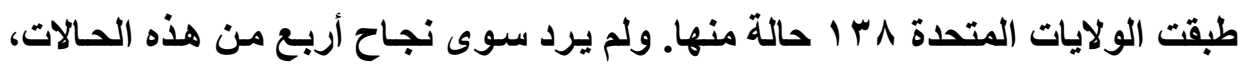

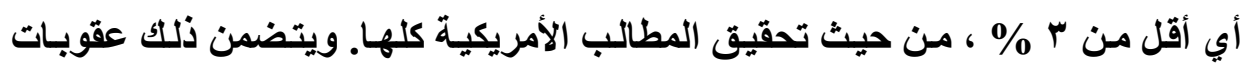


بسيطة ضد فنزويلا لتحسين ممارسـاتها البيئية، وكنلك ضد كوريـا الجنوبية، والهند، والاتحاد الأوروبي للحث على تغيير سياسات تجارية . فى حين أن البلان التي تعرضت لعقوبات اقتصادية موسعة استجابت لمـا طلب التبان

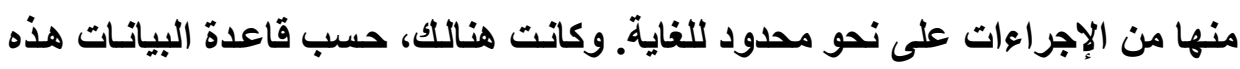

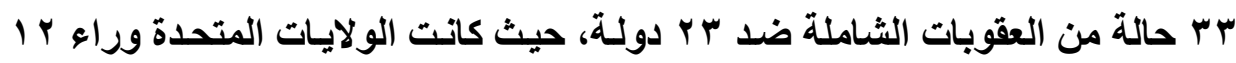

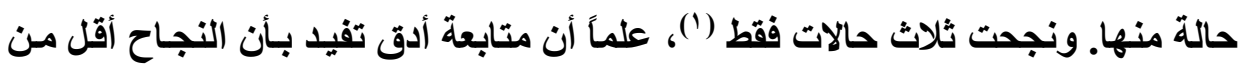
ذلك .

وهذا لا يغنى أنتا نرى أن تلك العقوبات الاقتصادية غير مجدية ؛ غير أنتا

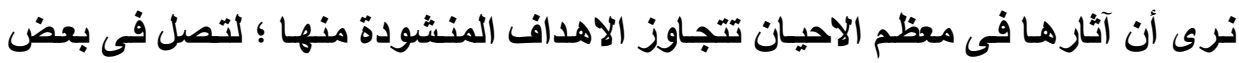

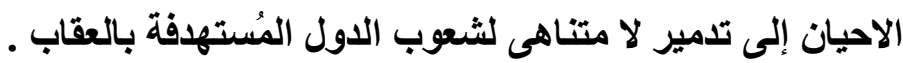

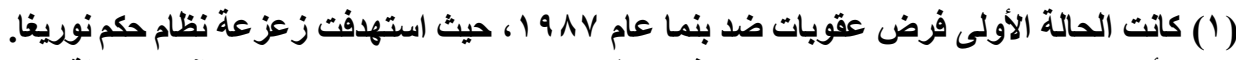

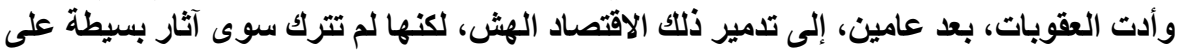

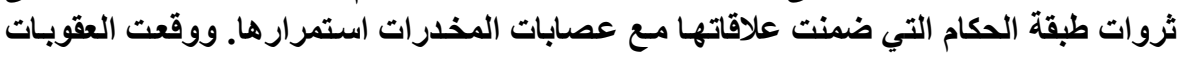

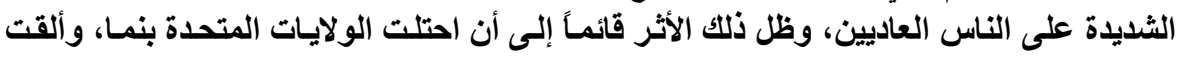

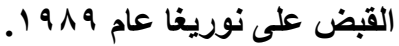

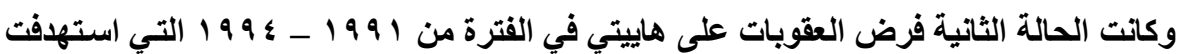

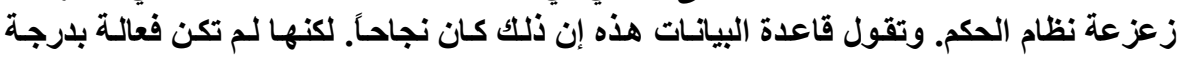

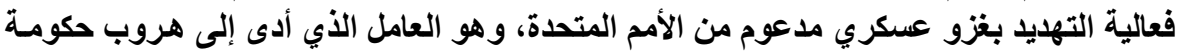

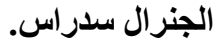

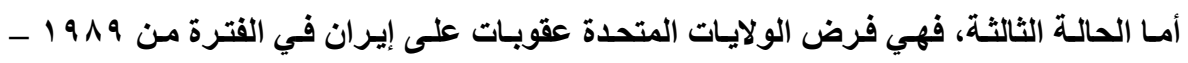

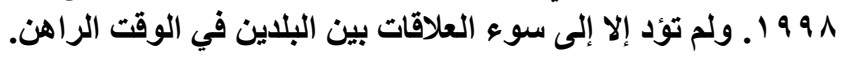


لا يمكنتا أن نوصس بإلغاء العقوبات الاقتصادية الدولية ؛ لمـا تخلفه من آثار اقتصادية واجتماعية مدمرة تصيب الفئات الاكثر فقرا بشكل رئيسى ؛ وذلك لمـا تمثلـه من أداة للردع الدولى ؛ وخيـار استراتيجى يستخدم في أحيـان كثيرة لتجنب ويلات

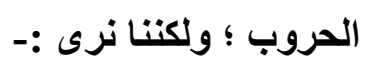

1- أن تكون تلكك العقوبات أكثر انضباطية بحيث لا تتجاوز أهدافها المعلنة ؛ وذلك

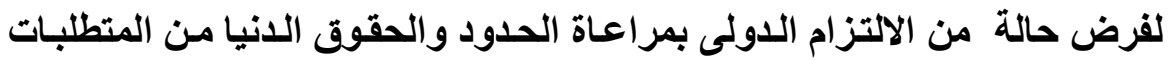
الاساسية لحياة كريمة للبشرية جمعاء .

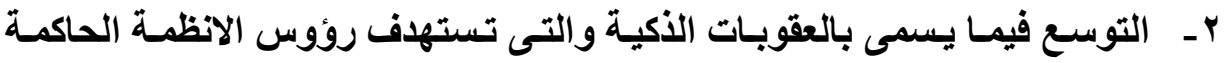

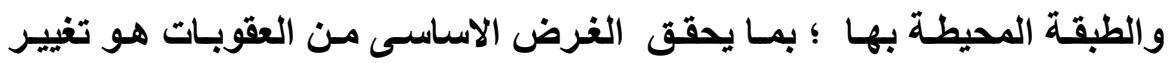

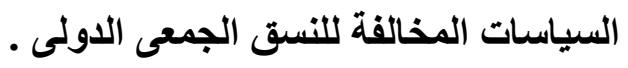

rــ التزام الجهات الاشرافية الدولية على العقوبـات الدولية كالأمم المتحدة ومجلس

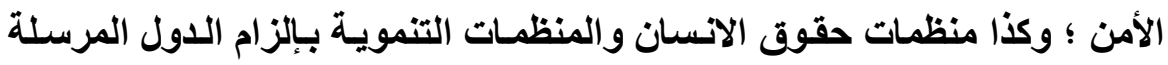
للعقاب بعدم تدمير البيئة البشرية المحيطة بشعوب الدول المستقبلة للعقاب ؛ وذللك

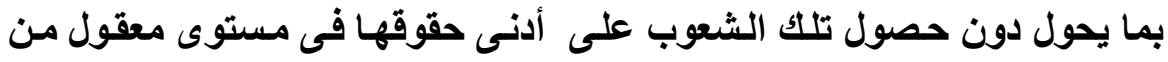

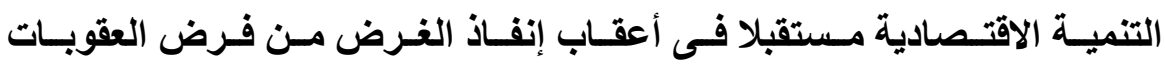
الاقتصادية الدولية . 


\section{المراجع}

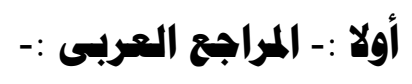

1- السيد أبـو عطيـة ؛ الجزاعات الدوليـة بين النظريـة والتطبيق ؛ مؤسسة الثقافة

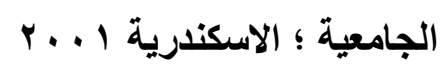

r - القيتوري الحوسين حسين، العلاقات الليبية الأمريكية شقاق أم وفاق، دار النهضة

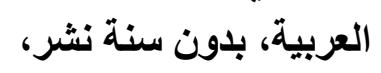

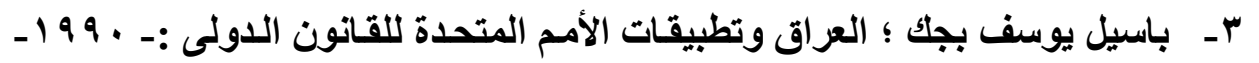

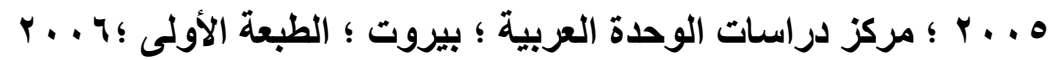

ع - ت تيم نبلـوك ؛ " العقوبـات والمنبـوذون فى الشرق الأوسط :ـ العراق - ليبيـا -

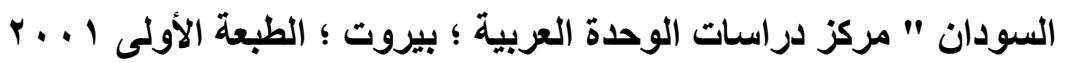

هـ جمال محى الدين ؛ العقوبـات الاقتصادية للأمم المتحدة ؛ الدار الجامعية الجديدة

$$
\text { r... } 9
$$

7- خلف بـو بكر " العقوبـات الاقتصادية فـى القـانون الدولى المعاصـر " ؛ ديـوان

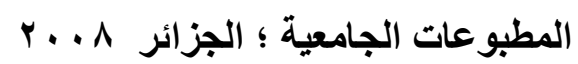

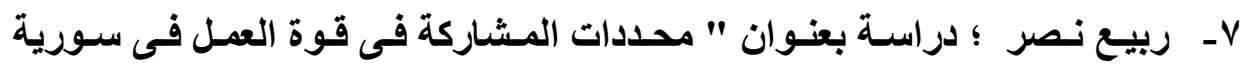

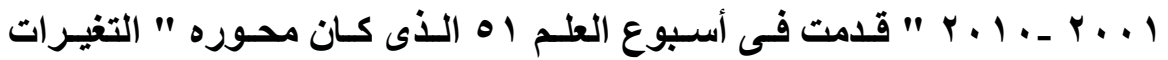

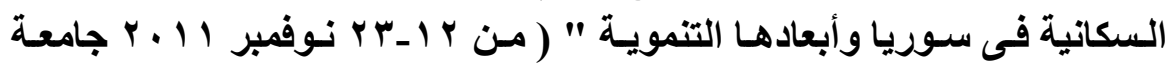

$$
\text { دمشق ) }
$$

1ــ رقية عواشرية " حماية المدنيين والأعيان المدنية فى المنازعات الملسلحة غير

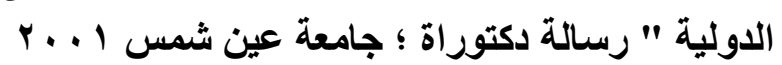

9- سولاف سليم " الجزاعات الدولية غير العسكرية " رسالة ماجستير ؛ جامعة سعد

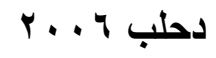


• 1 ـ سكوت لاسنسكى " الأردن والعراق : بين التعـاون والأزمـة "تقرير صسادر عن معهد السلام الأمريكى

11 ـ على صادق ابو هيف ؛ القانون الدولى العام ؛ مشأة المعارف ؛ الإسكندرية r ا ـ عمـر سـعد الله ؛ القـانون الـدولى لحـل النزاعـات ؛ دار هومـة للطباعـة والنـشر

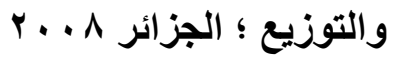

ب ا ـ فاتــة عبـد العـال أحمـد ؛ العقوبـات الدوليـة الاقتصادية ؛ دار النهضة العربيـة ؛

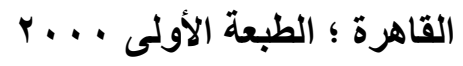

ـ 1 ـ فتيحة ليتيم " عقوبات الأمم المتحدة الاقتصادية وآثار ها على حقوق الإنسان فى إنى

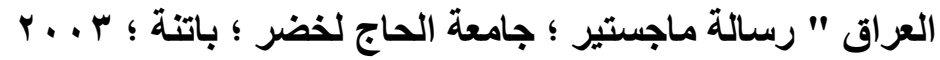
ه 1 ـ محمد جمال بـاروت ؛ مستح المسارات الكلية لتطور الاقتصاد السورى ؛ دمشت:

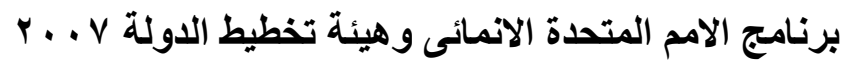

4 ا ـ مصطفى أحمد حامد رضوان " دراسة حالة الفقر فى مصر - حجمـه ؛ وأسبابه ؛

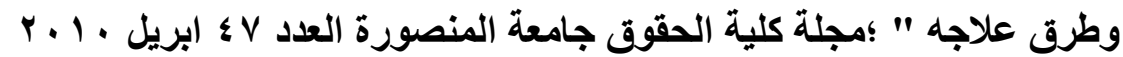
V ا ـ مصطفى أحمد رضوان كتاب التنمية والتخطيط الاقتصادى ؛ الطبعة الرابعة ؛

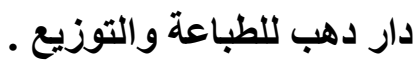

1 1 ـ هـانز كريستوف فون سبونيك ؛ تشريح العراق : عقوبـات التدمير الشامل التى التى

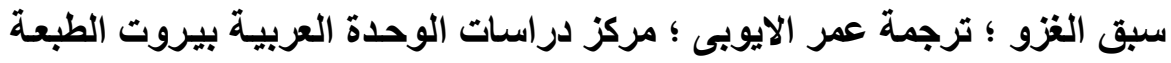

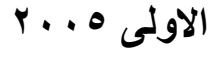

9 اـ هويدا محمد عبد المنعم ؛ العقوبـات الدولية وأثرهـا على حقوق الإنسان ؛ مهيب

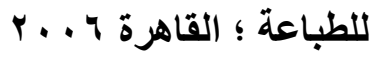

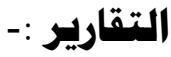
I - تقرير آفاق الاقتصاد الاقليمى الصادر عن صندوق النقد الدولى - منطقة الشرق

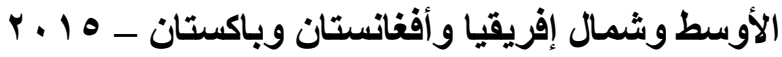


د/ مصطفى أحمد حامد رضوان

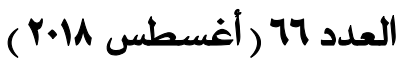

r- التقرير الاستراتيجي العربي، مركز الدراسـات السياسية والإستراتيجية بـالأهرام،

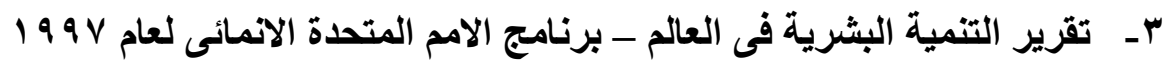

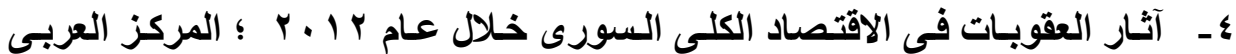
للابحاث ودراسة السياسا ت ؛ معهد الدوحة الأئة

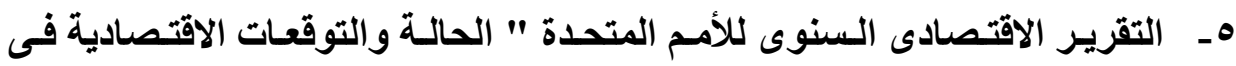

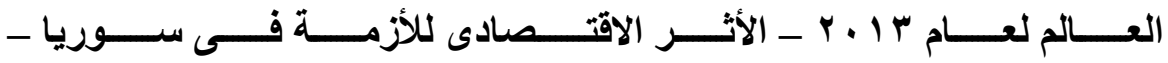

http://enabbaladi.org

7- البنك الدولى :- الموجز الفصلى لمنطقة الشرق الاوسط وشـمال أفريقيا ؛ يوليو

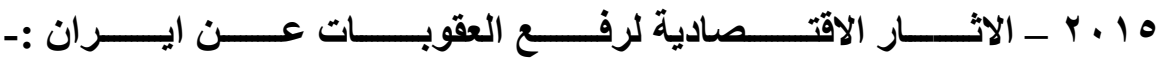

http://www.albankaldawli.org/ar/region/mena

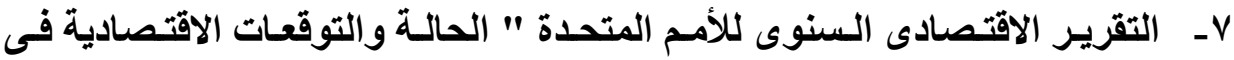

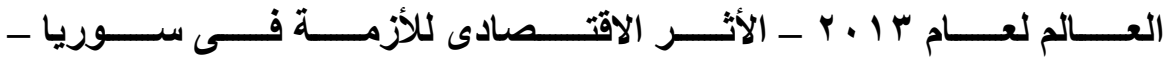

/http://enabbaladi.org

الاقتالات الصحفية والمواقع الالكتزونية :-

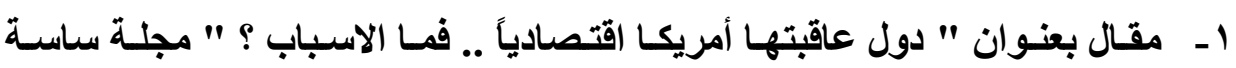
بوست : - بوw.sasapost.com/u-s-economic

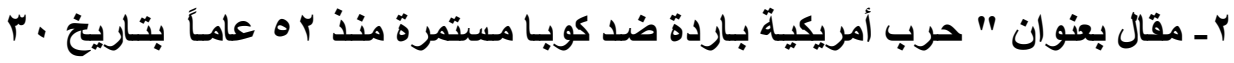
اكتوبر \& 1 ـ ب موقع نون بوست :-

r- نبيـل مـرزوق " العقوبـات الاقتصادية :- خنق بطى للنظـام السورى " ؛ مركز

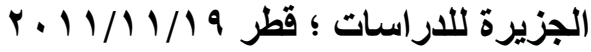

http://studies.aljazeera.net/reports/2011/11/20111119102491635 25.htm

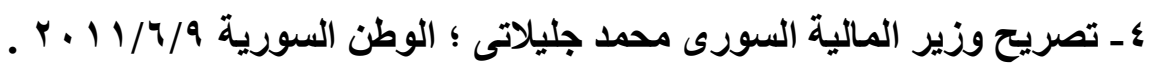

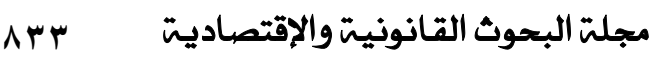


د/ مصطفى أحمد حامد رضوان

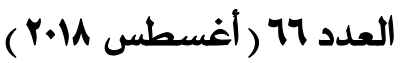

هـ أديب مبالة " محافظ البنك المركزى السورى " فى تصريح خـاص لجريدة الوطن

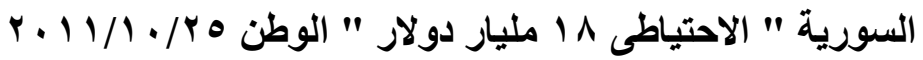

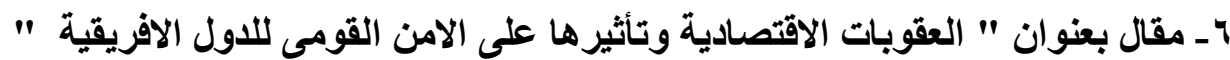

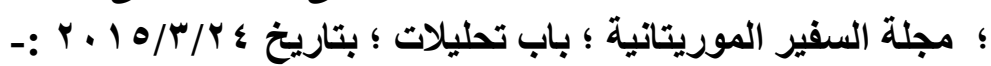

http://essevir.mr/index.php/287013-10-03-14-11-07/12521-201503-24-18-03-27.html

Vـ مقالة رامى خورى بعنوان " الأردن الايمقراطى : يجذب الأنار ولكنه لم يتحقق بعد

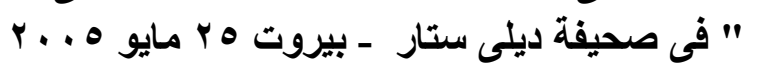

^ـ مقالـة حسن فتـاح بعنوان " بريـــ عمـان : بعد السقوط " في صـيفة ذى نيوز

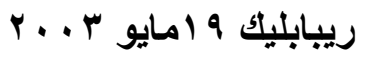

9- مقالة ديفيد شنكر بعنوان " الرقص مـع صدام :- التانجو الاستراتيجى للعلاقات

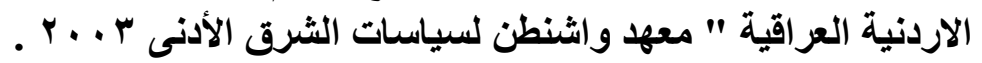

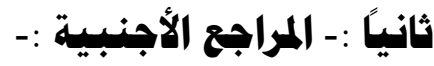

1- Andrew Mack, Asif Khan, «UN Sanctions: a Glass Half Full?»,p.161, Disponible sur le site internet-www.eyeontheun.org/assets/attachments/../andrew _mack_statement.pdf

2- Arya Neil, «Economic sanctions: the kinder, gentler alternative. $\ll$ ?

www.informaworld.com/smpp/.../content $\sim \mathrm{db}=\mathrm{all} \sim \operatorname{content}=\mathbf{a}$ 790526054.,

3- Ali Mostashari, « The Impacts of U.S. Sanctions on the Iranian Civil Society: Consequences for Democratization», p.1, Disponible sur le site internet

www.news4iran.info/The\%20Impacts\%20of\%20US\%20san ctions.pdf 
د/ مصطفى أحمد حامد رضوان

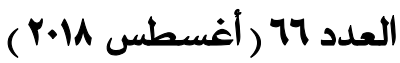

4- C.P. Vincent, The Politics of Hunger: The Allied Blockade of Germany, 1915-1919 (Athens, Ohio, Ohio University Press, 1985).

5- C. Phillipson, The International Law and the Custom of Ancient Greece and Rome (London, MacMillan, 1911),

6- Chingono Heather, «Zimbabwe sanctions: An analysis of the "Lingo" guiding the perceptions of the sanctioners and the sanctionees ", African Journal of Political Science and International Relations, Vol. 4, February 2010.

7- Hani Mansourian, « The Human Cost of Sanctions on Iran ", 03November 2010 'Disponible sur le site internet-:http://www.stumbleupon.com/su/2tcxGB/muftah.o rg/\%3Fp\%3D403

8- Micah Kaplan, «North Korean Economic Sanctions», Journal of International Relations, Volume 9, Spring 2007,

9- J. Muldoon, Popes, Lawyers, and Infidels. The Church and the Non-Christian World 1250-1550 (Philadelphia, University of Pennsylvania Press, 1979); and S.K. Stantchev, Embargo: The Origins of an Idea and the Implications of a Policy in Europe and the Mediterranean, ca. 1100 - ca. 1500 (Michigan, University of Michigan, 2009

10- John Baldwin, Masters, Princes and Merchants; the Social View of Peter the Chanter and his Circle, Vol. I, (Princeton, New Jersey, Princeton University Press 1970) 
د/ مصطفى أحمد حامد رضوان

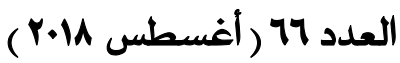

11- S.K. Stantchev, Spiritual Rationality: Papal Embargo as Cultural Practice (Oxford, Oxford University Press, 2014

12- Krishna Gagné,«Une analyse de la sanction économique en droit international "«Université de Montréal, Avril 2005,p6.Citant: Le Nouveau Petit Robert 1997 s. v.« sanction ». [Dictionnaire Robert] .

13- Lektzian David, «Making Sanctions Smarter: Are Humanitarian Costs an Essential Element in the Success of Sanctions? ", Norwegian Red Cross,International Peace Research Institute, Oslo, norway, 2003.

14- Thiébaut-Azadeh Kian, « L'Iran entre sanctions, destructions et Négociations», Revue Internationale Et Stratégique, Éditions Dalloz/RIS, Paris, 2008.

15- Tehindrazanarivelo Djacoba Liva, Les Sanctions des Nations Unies et leurs effets secondaires: assistance aux victimes et voies juridiques de prévention‘Presses Universitaires de France, Paris, 1ére édition, 2005. 